\title{
Mineralogical evolution of the northern Bossoroca ophiolite, São Gabriel terrane
}

\author{
Amanda Juliano Massuda' (D, Léo Afraneo Hartmann* (D), Gláucia Nascimento Queiroga² (D), \\ Marco Paulo de Castro² (D), Carolina Gonçalves Leandro' (D), Jairo Francisco Savian' (D)
}

\begin{abstract}
Mineralogical evolution of ophiolites is significant to understand paleo-oceanic crust and mantle requiring multi-proxy techniques to identify steps in the processes. We studied the Bossoroca ophiolite from the southern Brasiliano Orogen, a prime example of Tonian accretion to an oceanic island arc. Integration of field geology, aeromagnetometry, aerogamaspectrometry, electron microprobe analyses, and compositional maps of minerals led to the decoding of oceanic and continental processes. The ophiolite is highly magnetic and low-K and is positioned at the base of the superstructure. We studied amphibolite, tourmalinite, and chromite-talc-magnesite granofels from the ophiolite, Capivaras diorite from the Cambaí Complex infrastructure and one metavolcanoclastic rock from the Vacacaí Group superstructure. Honblende is zoned in all rock types. Low-Ti hornblende is compatible with medium-pressure metamorphism at $7 \mathrm{kbar}$. This M1 to M2 amphibolite facies resulted in the widespread association of olivine + talc in metaserpentinite. Dravite is similar to tourmaline from the Ibaré ophiolite. Andesine and oligoclase are dominant and albite minor. Cr-spinel in granofels recrystallized in greenschist facies; host rock originated by carbonatization of serpentinite formed in the oceanic crust along with chloritite and tourmalinite. Serpentinite rare earth elements (REE) suggest origin in depleted mantle peridotite. The ophiolite evolved in the Adamastor Ocean until incorporation into the island arc.
\end{abstract}

KEYWORDS: Bossoroca ophiolite; chromite-talc-magnesite granofels; tourmalinite; metasomatism; aerogeophysics.

\section{INTRODUCTION}

Metasomatic rocks from the oceanic crust and mantle are significant repositories of information on ophiolites and help unravel the evolution of collisional orogens. Hydration of harzburgite generates extensive serpentinite in both mid-ocean ridge and supra-subduction zone environments. The depletion of the residual ultramafic rocks (metaserpentinite) in most elements (e.g., $\mathrm{Al}, \mathrm{Ti}, \mathrm{Ca}, \mathrm{Na}$ ) and redeposition within

\section{Supplementary data}

Supplementary data associated with this article can be found in the online version: Supplementary Table A1, Supplementary Table A2, Supplementary Table A3, Supplementary Table A4, Supplementary Table A5, Supplementary Table A6, Supplementary Table A7, Supplementary Table A8, Supplementary Table A9, Supplementary Table A10, Supplementary Table A11, Supplementary Table A12, Supplementary Table A13, Supplementary Table A14, Supplementary Table A15, Supplementary Table A16.

${ }^{1}$ Universidade Federal do Rio Grande do Sul - Porto Alegre (RS), Brazil. E-mails: amanda.juliano027@gmail.com, leo.hartmann@ufrgs.br, carolina.leandro@ufrgs.br, jairo.savian@ufrgs.br

${ }^{2}$ Universidade Federal de Ouro Preto - Ouro Preto (MG), Brazil, E-mails: glauciaqueiroga@yahoo.com.br,marco_pcastro@yahoo.com ${ }^{*}$ Corresponding author. and in host rock of serpentinite leads to the formation of metasomatic rocks, particularly blackwall (rodingite, chloritite). Chloritites are characteristic rocks (e.g., Barriga and Fyfe 1983, Dubińska et al. 2004, Arena et al. 2017), whereas massive and disseminated tourmaline derives from oceanic fumaroles (e.g., Arena et al. 2019, Hartmann et al. 2019). Carbonation of serpentinite in the oceanic crust leads to generation of chromite-talc-magnesite granofels.

Minerals are repositories of primary information regarding the evolution of the metamorphosed oceanic crust and mantle. Mantle, oceanic and obduction processes in Tonian ophiolites are comparable to Phanerozoic associations (Stern 2018). Following obduction onto island arcs, ophiolites become sequentially metamorphosed during protracted accretionary and collisional orogenies. The search for minerals formed in the oceanic lithosphere prior to metamorphism results in the understanding of specific processes.

Extensive $(2,000 \mathrm{~km}$ long) exposure of the TonianCryogenian crust includes ophiolites in the Arabian-Nubian Shield (Stern 2018) and finds correlation with coeval terranes in South America. The Brasiliano collisional orogen $(4,000 \times 1,500 \mathrm{~km})$ is the Neoproterozoic-Cambrian backbone of South America (e.g., Hartmann and Delgado 2001). The orogen is comparable in scale to the Himalayas and formed by similar accretionary to continental collisional processes. Ophiolites are known along the orogen (Suita 
et al. 2004), such as the Araguaia belt in the north (Hodel et al. 2019, Barros and Gorayeb 2019, Souza et al. 2019), the Brasília belt in the center (Strieder and Nilson 1992), the Araçuaí Belt in the east (Queiroga et al. 2007, Amaral et al. 2020), the Borborema Province in northeast (Caxito et al. 2014, Santos et al.2015), and the Dom Feliciano belt in the south (e.g., Arena et al. 2016). U-Pb geochronology of metasomatic and igneous zircon from oceanic rocks by Arena et al. $(2016,2017,2018,2019)$ and Hartmann et al. (2019) reinforced the timing of ophiolite evolution between $920-715 \mathrm{Ma}$, but significant information remains encoded in metasomatites. Aerogeophysical investigations by Fernandes et al. (1995) and Hartmann et al. (2016) shed light on the regional distribution of the main tectonic units and their boundaries.

We focused on the northern Bossoroca ophiolite, Tonian São Gabriel terrane (e.g., Babinski et al. 1996, Lena et al. 2014), southern Brazil, because of the presence of metasomatic rocks from the oceanic crust - chromite-talc-magnesite granofels and tourmalinite. Host oceanic island-arc rocks were also studied to establish controls on the evolution of the ophiolite Capivaras diorite (Garavaglia et al. 2002) from the Cambaí Complex infrastructure and Campestre Formation metavolcanoclastic rock from the Vacacaí superstructure.

Main techniques included geological, aeromagnetometric, and aerogamaspectrometric surveys and electron microprobe analyses of minerals from several rocks, including compositional maps and backscattered electron images of hornblende, tourmaline, Cr-spinel, and whole-rock chemical analyses of serpentinite and chromite-talc-magnesite granofels. Hornblende grew during low-amphibolite and prehnite facies. Studied dravite has composition akin to oceanic tourmaline. We established significant constraints on the evolution of metasomatic rocks from the Bossoroca ophiolite as part of the Brasiliano Orogen, integrated with accretionary orogens of Gondwana.

\section{GEOLOGICAL SETTING}

The Bossoroca ophiolite is a prime Tonian (920-710 Ma; Hartmann et al. 2019) association of oceanic crust and mantle rocks in the São Gabriel terrane $(100 \times 70 \mathrm{~km})$. This juvenile portion of the Dom Feliciano Belt in southern Brazil and Uruguay (Fig. 1) exemplifies the generation of the protoAdamastor Ocean during the early rupturing of Rodinia as registered in the present Brazilian Shield (e.g., Basei et al. 2018, Hartmann et al. 2019).

The juvenile terrane (Babinski et al. 1996, Hartmann et al. 2011, Philipp et al. 2018) is (Figs. 1 and 2) an association of infrastructure Cambaí Complex granitic and gneissic rocks with superstructure Vacacaí Group volcanic, sedimentary, and volcaniclastic rocks. Oceanic and mantelic rocks form the Cerro do Ouro ophiolite, which contains the Cerro Mantiqueiras, Ibaré, Palma, Cambaizinho, and Bossoroca ophiolites; Caçapava North and Caçapava South may be additional ophiolites. This tripartite division organizes the stratigraphic relationship in the São Gabriel terrane. Additional ophiolites occur in the Porongos foldand-thrust belt both in southernmost Brazil and northeastern Uruguay - Capané (Arena et al. 2019), Candiotinha (Xavier et al. 2018), Arroio Grande (Ramos and Koester 2015), and Cerro La Tuna (Peel et al. 2018).

The Cerro Mantiqueiras and Cambaizinho ophiolites are in the infrastructure of the island-arc, whereas the Bossoroca ophiolite was obducted into the base of the superstructure.

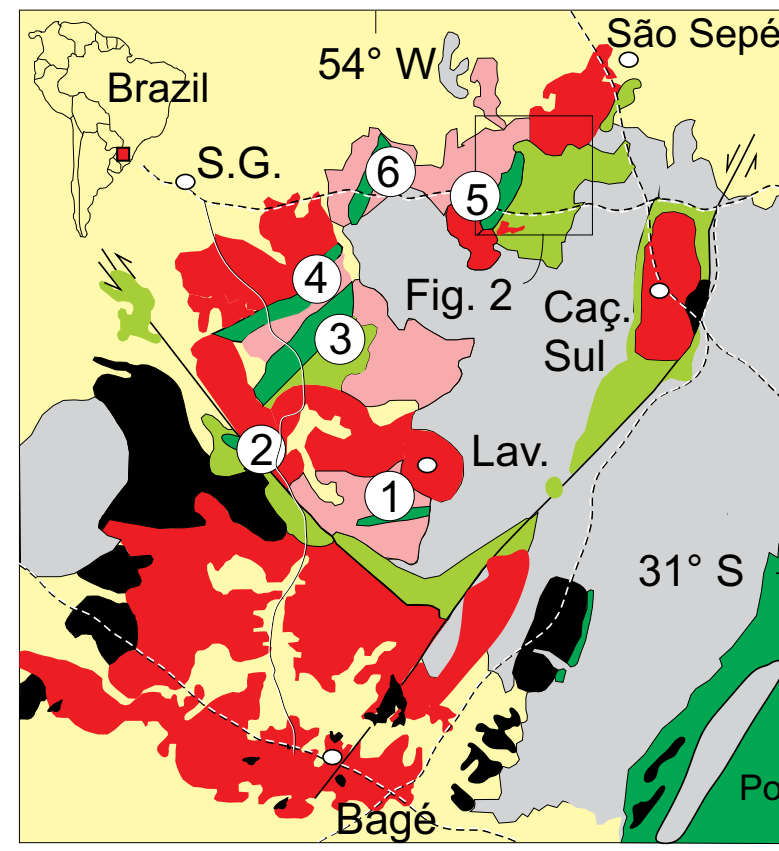

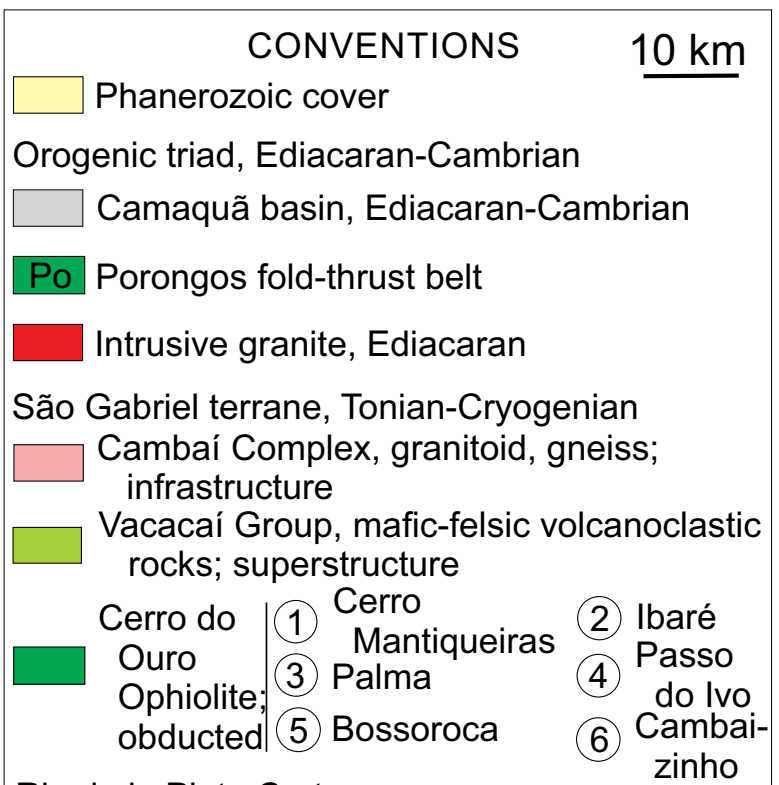

Rio de la Plata Craton

Santa Maria Chico Granulite Complex, other gneisses, Paleo-Mesoproterozoic

- Town, Caç. Sul = Caçapava do Sul S.G. = São Gabriel Lav. = Lavras do Sul Highway Unpaved road

Figure 1. Geological map of São Gabriel terrane (Hartmann et al. 2019) displaying two geotectonic environments of ophiolites intrusive either into the infrastructure Cambaí Complex (ophiolites numbered 1,4 , and 6 ) or at the base of the superstructure Porongos Group (numbered 2, 3, and 5). Inset shows location of Figure 1. Position of Figure 2 indicated. 


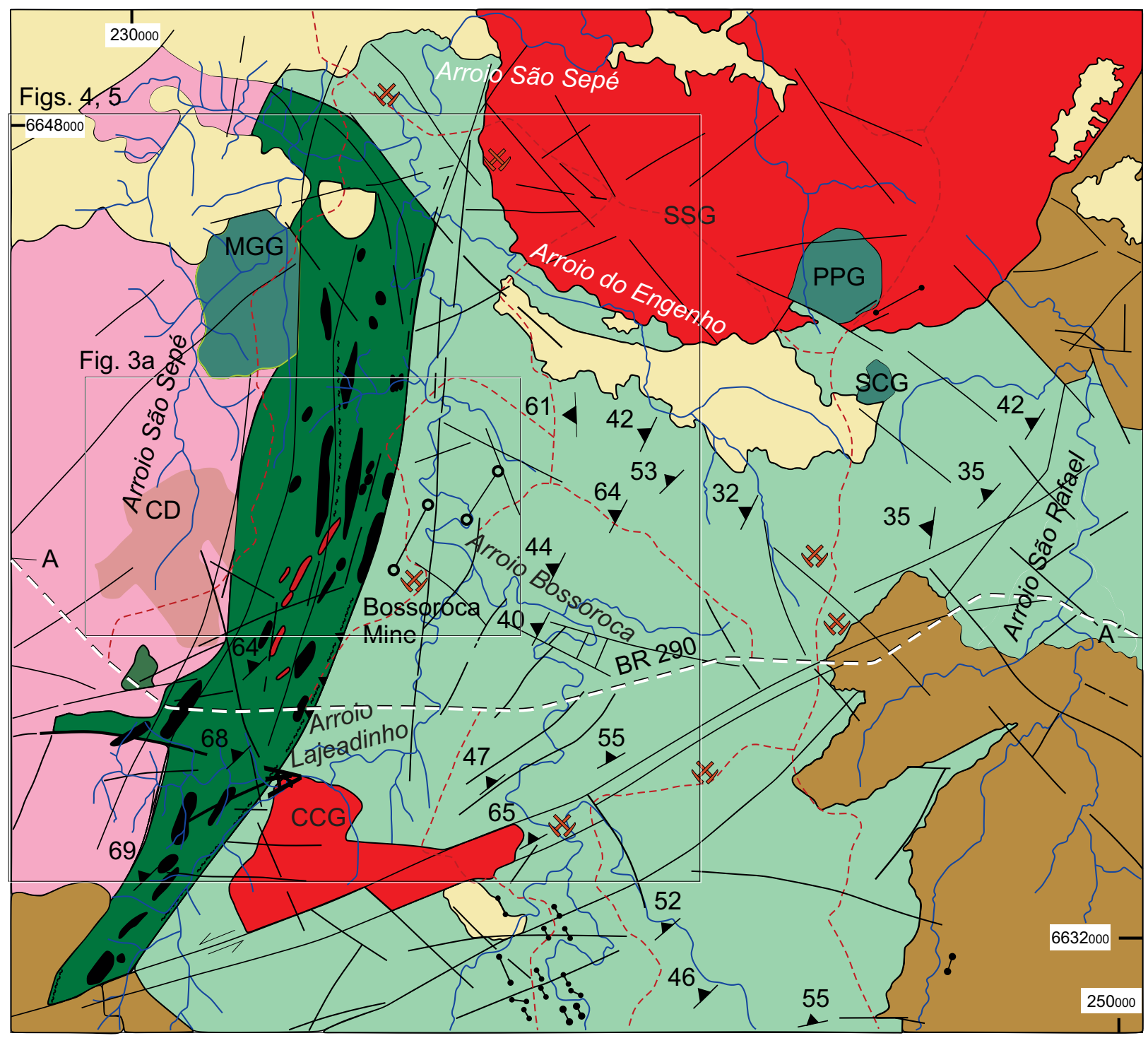

A Arroio São Sepé Arroio Lageadinho Arroio Bossoroca

Arroio São Rafael A

\begin{tabular}{|c|c|}
\hline \multirow{2}{*}{$\begin{array}{l}\text { Paraná Basin sedimentary rocks (Paleozoic, Mesozoic) and } \\
\text { alluvium }\end{array}$} & \multirow[b]{2}{*}{ Boss. = Bossoroca } \\
\hline & \\
\hline \multirow{2}{*}{$\begin{array}{l}\text { Granite pluton; São Sepé Granite (SSG), Cerro da Cria Granite } \\
\text { (CCG) (612 Ma) }\end{array}$} & $\begin{array}{l}\text { Gold mine, } \\
\text { inactive }\end{array}$ \\
\hline & Foliation \\
\hline Camaquã Basin, sedimentary and volcanic rocks (610-570 Ma) & ? Dike \\
\hline \multicolumn{2}{|c|}{$\begin{array}{l}\text { Bossoroca ophiolite (Arroio Lajeadinho Formation), including serpentinite (black), } \\
\text { BIF (red), Mata Grande Gabbro (MGG), Pedras Pretas Gabbro (PPG) and Santa } \\
\text { Catarina Gabbro (SCG) (950-700 Ma) - Cerro do Ouro Ophiolite; obducted }\end{array}$} \\
\hline Vacacaí Group (Campestre Formation) (750 Ma); superstructure & $\begin{array}{l}\text { Creek } \\
\text { Unpaved road }\end{array}$ \\
\hline $\begin{array}{l}\text { Cambaí Complex (CC), including Capivaras diorite (CD) } \\
(750-695 \mathrm{Ma}) \text {; infrastructure }\end{array}$ & $\overrightarrow{B R} 290$ Highway \\
\hline
\end{tabular}

Figure 2. Geological map of Bossoroca ophiolite (modified from Saalmann et al. 2006, Gubert et al. 2016). Position of ophiolite at the base of the superstructure (top of infrastructure) displayed. Position of Figures 3A, 5, and 6 indicated. Position of displayed section (simplified from Gubert et al. 2016) shown in map as A-A'. 
This geological setting is comparable to the extensive $(2,000$ $\times 200 \mathrm{~km}$ ), juvenile Arabian-Nubian Shield (Stern 2018), where gold deposits are found in the ophiolites present in the base of the superstructure. The Bossoroca ophiolite has a systematic presence of gold specks in alluvium and hosts the exhausted Bossoroca mine in the superstructure $1 \mathrm{~km}$ east of the ophiolite.

The tripartite stratigraphic division of the juvenile terrane organizes rock associations in a tectonic framework (Tab. 1). As pointed out by Hoerlle et al. (2019), the terrane is "a Neoproterozoic metavolcanic-sedimentary sequence, represented by the Cambaizinho, Bossoroca and Palma Complexes intruded by juvenile calc-alkaline gneisses of the Cambaí Complex." The terrane was subdivided into different formations and complexes (e.g., Goñi et al. 1962, Koppe et al. 1985, Koppe and Hartmann 1990, Machado et al. 1990, Babinski et al. 1996, Hartmann et al. 1999, 2007, 2011, Saalmann et al. 2006). Our suggestion of nomenclature of the island arc is linked to either the plutonic or supracrustal origin of the rocks and is presently expanded to include the extraneous, obducted ophiolite. The profusion of stratigraphic names used in the terrane is thus simplified and organized within a simple, consistent tectonic frame (Cerva-Alves et al. 2020).

The $2-\mathrm{km}$ wide Bossoroca ophiolite dips $60-80^{\circ}$ toward NNW along $20 \mathrm{~km}$. The ophiolite in the Campestre village transect (Figs. 2 and 3) has many lenses of serpentinite (50$1,000 \mathrm{~m}$ ), amphibolite, quartz-plagioclase granofels, banded iron formation, and metachert (e.g., Saalmann et al. 2006,
Gubert et al. 2016, Hartmann et al. 2019). Metasomatic chloritite and tourmalinite are minor, but significant (Hartmann et al. 2019). Mantelic rocks are more abundant in the eastern portion and supracrustal rocks in the west, reminiscent of the oceanic mantle to the crust tectonic stratigraphy. Main foliation strikes NNE and dips at a high angle to NNW in rocks displaying dominantly low-amphibolite facies assemblages, e.g., amphibolite has hornblende + plagioclase, metaserpentinite has olivine + talc (jackstraw texture). This S2 foliation (Saalmann et al.2006, 2007) marks the obduction of the ophiolite into the oceanic island arc. $\mathrm{S} 1$ is restricted to rootless folds contained in S2. Transcurrent faulting and local thrusting occurred in succession. Older Rio de La Plata Craton rocks are present below the juvenile terrane. The terrane was thrust over the Rio de la Plata Craton at an undetermined age (possibly 650 $\mathrm{Ma})$; the isotopic composition of younger São Sepé Granite $(550 \mathrm{Ma})$ and other granites supports the interpretation. A metacraton was thus recognized in the region (Santos et al. 2019). Petrological and isotopic evidence from Ediacaran granites (Remus et al. 1999) point to the presence of a cratonic crust underneath the São Gabriel terrane, an interpretation reinforced by a magnetotelluric survey (Bologna et al. 2019). Arcuate thrusts identified from aeromagnetometric data by Travassos (2014) indicate displacement of the juvenile terrane from the NW to the SE. The Bossoroca ophiolite has arcuate shape pointing to east. This overthrusting occurred on a regional, $200 \mathrm{~km}$-scale at $650 \mathrm{Ma}$, because all Ediacaran rocks display crustal-reworking geochemical and isotopic characteristics in the Sul-Riograndense Shield.

Table 1. Stratigraphy of São Gabriel terrane (São Gabriel island arc + obducted ophiolites) and associated units, with selected examples and approximate ages.

\begin{tabular}{|c|c|c|c|}
\hline Geotectonics & Stratigraphic unit & Description & Age, Ma \\
\hline Intraplate & Paraná Basin & $\begin{array}{l}\text { Voluminous siltite, some lamite, } \\
\text { conglomerate, limestone }\end{array}$ & $450-60$ \\
\hline Post-orogenic & $\begin{array}{c}\text { São Sepé, Ramada, } \\
\text { São Manoel, Lavras Granites }\end{array}$ & Shallow level, strong contact aureole & $600-550$ \\
\hline Foreland & Camaquã Basin & Volcanics, trachyandesite, sedimentary rocks & 575 \\
\hline \multirow[t]{2}{*}{ São Gabriel island-arc } & $\begin{array}{c}\text { Superstructure, } \\
\text { Vacacaí Group - Campestre, } \\
\text { Pontas do Salso, Bela Vista, } \\
\text { Passo Feio (in part) Formations }\end{array}$ & $\begin{array}{l}\text { Island-arc volcanics and sediments, } \\
\text { turbidite, graywacke, tuff, andesite }\end{array}$ & 755 \\
\hline & $\begin{array}{c}\text { Infrastructure, } \\
\text { Cambaí Complex - Lagoa da Meia-Lua } \\
\text { Suite, Sanga do Jobim granite, } \\
\text { Cerca de Pedra granodiorite, } \\
\text { Capivaras diorite, Imbicuí gneiss }\end{array}$ & $\begin{array}{l}\text { Granitic rocks, syntectonic, no } \\
\text { contact metamorphism on } \\
\text { ophiolites or Vacacaí Group. }\end{array}$ & $\begin{array}{l}(770), \\
730-700, \\
690\end{array}$ \\
\hline \multirow[t]{2}{*}{ Oceanic crust + mantle } & $\begin{array}{l}\text { Cerro do Ouro Ophiolite: Ophiolites } \\
\text { Cerro Mantiqueiras, Cambaizinho, } \\
\text { Palma, Ibaré, portions of Passo Feio }\end{array}$ & $\begin{array}{l}\text { Ultramafic, mafic, andesitic, } \\
\text { volcanosedimentary rocks. }\end{array}$ & $920-720$ \\
\hline & $\begin{array}{l}\text { Bossoroca ophiolite } \\
\text { (Arroio Lajeadinho Formation) }\end{array}$ & $\begin{array}{l}\text { Steeply dipping foliation, NNE direction, } \\
\text { WNW dip. Talc-olivine metaserpentinite, } \\
\text { amphibolite, BIF, gabbro-harzburgite. } \\
\text { Metasomatites - Chromite-talc-magnesite } \\
\text { fels, tourmalinite, rodingite, chloritite. } \\
\text { Obducted at base of suprastructure. } \\
\text { Gold specks in alluvium. }\end{array}$ & $920-720$ \\
\hline
\end{tabular}


The ophiolite is in contact to the west with deformed granitic rocks of the Cambaí Complex infrastructure. Most rocks show evidence of amphibolite facies metamorphism, including the selected Capivaras diorite. No evidence was observed of thermal metamorphism caused by these granitic rocks in the ophiolite. The honblende core and rim were considered magmatic in the Capivaras diorite (Garavaglia et al. 2002), but we interpret the evidence as corresponding to magmatic cores and metamorphic rims.

The superstructure Vacacaí Group (locally Campestre Formation) positioned to the east of the ophiolite is mostly volcanoclastic; rocks were metamorphosed in low amphibolite facies. Strong thermal metamorphism was overprinted on these supracrustal rocks in the northern portion by intrusion of the São Sepé Granite (Mattos et al. 2004) and in the southern portion by the Ramada and Cerro da Cria granites.

Metasomatic rocks - chromite-talc-magnesite granofels and tourmalinite - occur close to serpentinite and amphibolite within the ophiolite - similar geological relationship as described by Azer et al. (2019) in the Arabian-Nubian Shield. The Bossoroca ophiolite is, thus, a prime rock association to unravel the evolution of Tonian oceanic crust and mantle accreted to a juvenile island arc.

\section{MATERIALS AND METHODS}

Techniques reported here for the airborne geophysical survey of the shield by the Geological Survey of Brazil (CPRM 2010) include aerogammaspectrometry and aeromagnetometry and follow Hartmann et al. (2016). Data acquisition was carried out by Lasa Prospecções S.A. (CPRM 2010). The flight was at an elevation of $100 \mathrm{~m}$ above the terrain, line spacing at $500 \mathrm{~m}$ and control lines spaced $10,000 \mathrm{~m}$, oriented NS and EW. The survey covered $159,789.21 \mathrm{~km}$ of flights. Ten readings per second were made on the aeromagnetometer. All gamaspectrometer readings were taken one per second, with GPS positioning with an accuracy greater than $5 \mathrm{~m}$. Flight speed was $270 \mathrm{~km} / \mathrm{h}$, resulting in one reading every $7.5 \mathrm{~m}$ on the terrain for magnetometry and $75 \mathrm{~m}$ for gamaspectrometry. Border regions of the shield were also covered, including strips of the Paleozoic-Mesozoic Paraná Basin to the north, west, and south and the Quaternary coastal plain in the east. A Scintrex CS-2 equipment was used for the acquisition of magnetic data. Two equipment were used in two different airplanes for the acquisition of gamma spectrometric data, the Exploranium GR-820 and the Radiation Solutions Inc./RS500 spectrometers. Radar altimeters King 405 and Collins ALT-50 and barometers Fugro/Enviro were used in different airplanes to obtain the digital terrain model of the shield.

Total magnetic field and gamma spectrometric (potassium, thorium, and uranium channels) data processing was performed at Lasa Prospecções S.A., Rio de Janeiro, involving the application of Oasis Montaj routines, version 7.1.1 GEOSOFT. Maps of digital elevation model, anomalous magnetic field (AMF), total count, eTh and eU were generated. This remote sensing of rock types and lineaments allowed the contouring of the geology and interpretation of structures (e.g., Milligan and Gunn 1997, Nabighian et al. 2005).

Observation of satellite images was integrated with aerogeophysical data, followed by geological field survey in a 2-km wide EW Vila Campestre transect of the Bossoroca ophiolite. The survey involved collecting rock samples for laboratory studies, including a massive tourmalinite. Studied samples from the ophiolite include tourmalinite and associated chloritite, chromite-talc-magnesite granofels, serpentinite, amphibolite, and one sample from the Capivaras diorite in the host Cambaí Complex; location of samples in Suppl. Tab. A1. Polished thin sections (one per sample) were studied under the optical microscope at Universidade Federal do Rio Grande do Sul (UFRGS).

Electron microprobe analyses (EPMA) were performed using a JEOL JXA-8230 electron microprobe at Laboratório de Microscopia e Microanálises (LMIc) of the Department of Geology of Universidade Federal de Ouro Preto (UFOP). Several minerals were analyzed, as follows: hornblende (several crystals, $\mathrm{n}=101$ analyses) from samples C3P2 (amphibolite), C3P4 (metavolcanoclastic rock), and C3P17 (deformed diorite); tourmaline ( $\mathrm{n}=$ 18 crystals, $n=79$ analyses) from sample BO19; Cr-spinel and magnetite ( $\mathrm{n}=14$ crystals, 62 analyses $)$ from samples BO17 chloritite (1 sample), BO13 (1 sample), C3P10 (1 sample), and
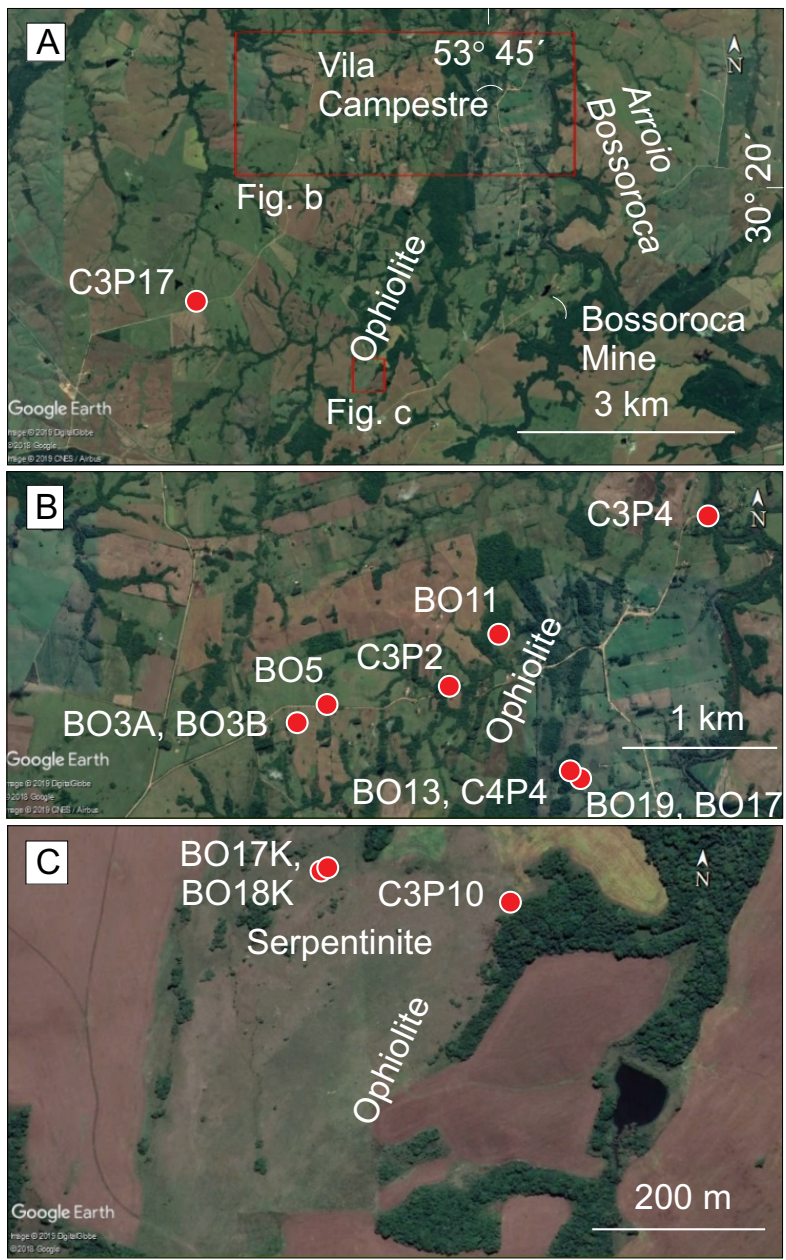

Figure 3. Satellite images of the studied region, northern Bossoroca ophiolite, Campestre transect. Location of studied samples indicated with red dot and number. 
C4P4 (1 sample) - chromite-talc-magnesite granofels; chlorite ( $\mathrm{n}=85$ analyses) from samples BO17 (chloritite), BO19 (tourmalinite), and C3P2 (amphibolite); plagioclase (several crystals, 61 analyses) in 1 sample, each of C3P2 (amphibolite), C3P4 (metavolcanoclastic rock,) and C3P17 (deformed diorite); orthoclase ( $\mathrm{n}=2$ crystals, $\mathrm{n}=6$ analyses) from sample C3P17 (deformed diorite); magnesite ( $\mathrm{n}=8$ crystals, 22 analyses) from 2 samples (C3P10, C4P4) of chromite-talc-magnesite granofels; talc ( $\mathrm{n}=4$ analyses) from sample C3P10 - chromitetalc-magnesite granofels; serpentine ( $\mathrm{n}=18$ analyses) from granofels samples C3P10, C4P4; clinopyroxene ( $\mathrm{n}=7$ analyses from deformed diorite sample C3P17, prehnite ( $\mathrm{n}=3$ analyses) from amphibolite sample C3P2, apatite ( $\mathrm{n}=12$ analyses) from granofels samples BO19 and BO17, and epidote ( $\mathrm{n}=7$ analyses) from deformed diorite sample C3P17. The electron beam was set at $15 \mathrm{kV}, 20 \mathrm{nA}, 5 \mu \mathrm{m}$ and the common matrix ZAF corrections were applied. Total iron content was taken as $\mathrm{FeO}$. Counting times on the peaks/background were 10/5 s for most of elements ( $\mathrm{Na}, \mathrm{Si}, \mathrm{Al}, \mathrm{Mg}, \mathrm{Fe}, \mathrm{Cr}, \mathrm{Ti}, \mathrm{Ca}, \mathrm{K}, \mathrm{Mn}, \mathrm{F}$, $\mathrm{Zr}, \mathrm{Cl}$, and $\mathrm{P}$ ) except for $\mathrm{Ba}, \mathrm{Sr}, \mathrm{Zn}$, and $\mathrm{Ni}(30 / 15 \mathrm{~s})$. Natural minerals and pure metals of the laboratory collection acted as standards during the analyses. All mineral formulae were calculated in Excel spreadsheets (GabbroSoft http://www.gabbrosoft.org/spreadsheets/). Plagioclase was calculated on the basis of $32 \mathrm{O} ; \mathrm{Fe}^{+3}$ and $\mathrm{Fe}^{+2}$ were calculated stoichiometrically. Additional methodology is in Supplementary Table A2. Selected chemical analyses of minerals are in Table 2 . All mineral analyses are given in Supplementary Tables A3, A4, A5, A6, A7, A8, A9, A10, A11, A12, A13, A14, and A15.

Back-scattered electron (BSE) and compositional maps were also obtained. BSE images $(n=33)$ were made of samples C3P2 (amphibolite), BO19 (tourmalinite), BO17 (chloritite), BO13, C3P10, C4P4 (chromite-talc-magnesite granofels),
C3P17 (deformed diorite), and C3P4 (metavolcanoclastic rock). Along with BSE images, compositional maps were made of several minerals in amphibolite (C3P2; $\mathrm{Al}, \mathrm{Ca}, \mathrm{Fe}, \mathrm{Mg}$, and $\mathrm{Ti}$ ), tourmalinite with chlorite (BO19; $\mathrm{Al}, \mathrm{Ca}, \mathrm{Fe}, \mathrm{Mg}, \mathrm{Na}, \mathrm{Si}$, and $\mathrm{Ti}$ ), and chromite-talc-magnesite granofels (BO13; $\mathrm{Mg}$, $\mathrm{Al}, \mathrm{Cr}, \mathrm{Ni}$, and $\mathrm{Fe}$ ). Mineral abbreviations follow Whitney and Evans (2010).

Photomicrographs were taken under the petrographic microscope in plane-polarized and crossed-nicols of amphibolite (C3P2), chlorite tourmalinite (BO19), chromite-talc-magnesite granofels (C3P10), deformed diorite (C3P17), and metavolcanoclastic rock (C3P4). BSE images cover the same area as in the thin-section registered in photomicrography.

Whole-rock chemical analyses of four serpentinite and two chromite-talc-magnesite granofels samples were made at Bureau Veritas, Canada. The analyses included the determination of REE elements (Suppl. Tab. A16).

\section{RESULTS}

Satellite images show wooded hill tops in parts of the ophiolite, surrounded by dominant undulated grasslands and farmlands (Fig. 3). The digital elevation model (Fig. 4) displays ophiolite at the distal rim of Ramada plateau at $200 \mathrm{~m}$ elevation. AMF reveals the presence of several dipoles, one located across the ophiolite (Fig. 5A). The ophiolite has low total count of $\mathrm{K} \%+\mathrm{eTh}+\mathrm{eU}<180 \mathrm{cps}$ (Fig. 5B), low eTh $<1.5$ ppm (Fig. 5C), and low eU $\sim 0$ ppm (Fig. 5D). The Cambaí Complex infrastructure and Vacacaí Group superstructure have higher emission rates of aerogammaspectrometry than the ophiolite, and the highest peak is in the post-tectonic São Sepé, Cerro da Cria, and Ramada Granites. These granites have intrusive relationships with the Cambaí Complex,

Table 2. Selected eletron microprobe analyses (wt.\%) of minerals from northern Bossoroca ophiolite. Samples: C3P2, amphibolite; C3P4, metavolcanoclastic rock; BO19, tourmalinite; BO13, chromite-talc-magnesite granofels; C3P10, chromite-talc-magnesite granofels; BO17, chloritite; C4P4, chromite-talc-magnesite granofels; C3P17, deformed diorite.

\begin{tabular}{|c|c|c|c|c|c|c|c|c|c|c|c|c|}
\hline Mineral & & & Tur & & & & & & & Mgs & Tlc & Di \\
\hline Sample & C3P2 & C3P4 & BO19 & BO13 & C3P10 & BO19 & BO17 & C3P2 & C3P4 & C4P4 & C3P10 & C3P17 \\
\hline Analysis & 10 & 4 & 20 & 9 & 21 & 11 & 18 & 70 & 38 & 28 & 34 & 14 \\
\hline $\mathrm{SiO}_{2}$ & 42.48 & 48.48 & 36.24 & 0.00 & 0.00 & 26.54 & 30.82 & 60.39 & 59.10 & 0.15 & 62.09 & 52.98 \\
\hline $\mathrm{TiO}_{2}$ & 0.19 & 1.18 & 0.54 & 0.13 & 0.07 & 0.02 & 0.06 & 0.00 & 0.00 & 0.01 & 0.01 & 0.06 \\
\hline $\mathrm{Al}_{2} \mathrm{O}_{3}$ & 15.90 & 6.70 & 31.56 & 6.23 & 19.03 & 21.58 & 19.54 & 23.88 & 25.62 & 0.47 & 0.17 & 0.80 \\
\hline $\mathrm{Cr}_{2} \mathrm{O}_{3}$ & 0.01 & 0.05 & 0.00 & 56.32 & 43.23 & 0.02 & 0.74 & 0.00 & 0.00 & 0.00 & 0.02 & 0.07 \\
\hline $\mathrm{FeO}$ & 15.24 & 12.76 & 7.06 & 33.59 & 32.75 & 18.06 & 6.19 & 0.87 & 0.09 & 6.54 & 1.66 & 7.09 \\
\hline $\mathrm{MgO}$ & 10.30 & 14.24 & 8.82 & 2.33 & 3.02 & 19.44 & 30.54 & 0.68 & 0.00 & 39.89 & 30.38 & 13.83 \\
\hline $\mathrm{CaO}$ & 10.61 & 12.80 & 0.68 & 0.00 & 0.07 & 0.01 & 0.02 & 5.22 & 7.59 & 0.33 & 0.00 & 23.39 \\
\hline $\mathrm{MnO}$ & 0.23 & 0.23 & 0.04 & 0.00 & 0.00 & 0.24 & 0.05 & 0.00 & 0.01 & 0.17 & 0.00 & 0.30 \\
\hline $\mathrm{Na}_{2} \mathrm{O}$ & 1.96 & 0.77 & 2.22 & 0.12 & 0.21 & 0.00 & 0.02 & 8.09 & 7.48 & 0.02 & 0.07 & 0.45 \\
\hline $\mathrm{K}_{2} \mathrm{O}$ & 0.24 & 0.24 & 0.01 & 0.09 & 0.08 & 0.04 & 0.00 & 0.11 & 0.04 & 0.03 & 0.07 & 0.02 \\
\hline $\mathrm{F}$ & 0.05 & 0.07 & 0.05 & 0.83 & 0.83 & 0.00 & 0.01 & 0.00 & 0.04 & 0.01 & 0.00 & 0.00 \\
\hline $\mathrm{Cl}$ & 0.02 & 0.09 & 0.00 & 0.07 & 0.05 & 0.01 & 0.00 & 0.05 & 0.00 & 0.02 & 0.04 & 0.01 \\
\hline Total & 97.23 & 97.61 & 87.22 & 99.71 & 99.34 & 85.96 & 87.99 & 99.29 & 99.97 & 47.64 & 94.51 & 99.00 \\
\hline
\end{tabular}


Vacacaí Group and Bossoroca ophiolite; the shallow magmatism caused intense contact metamorphic effects on the country rocks.

Field survey led to identification of chromite-talc-magnesite granofels (Fig. 6A), bare rock exposed along $300 \times$ $50 \mathrm{~m}$ in the forested hilltop. The rock is massive, grey colored, medium-grained, and has a few Cr-spinel seams; granofels dips steeply to NNW along with the ophiolite. The granofels has concordant contact with metaserpentinite and amphibolite in the few exposed locations. This tectonic contact coincides with S2 and was established during deformation at low-amphibolite facies, regional metamorphism. In addition, massive tourmalinite and dispersed tourmaline occur associated with chloritite (Fig. 6B), all units with similar concordant, tectonic contacts.

Field observations and petrography of studied samples, integrated with BSE images and EPMA analyses and compositional maps, display significant structural, mineralogical and textural features (Figs. 7, 8, 9, 10 and 11). The amphibolite is massive with diffuse foliation (S2) directed to NNE and

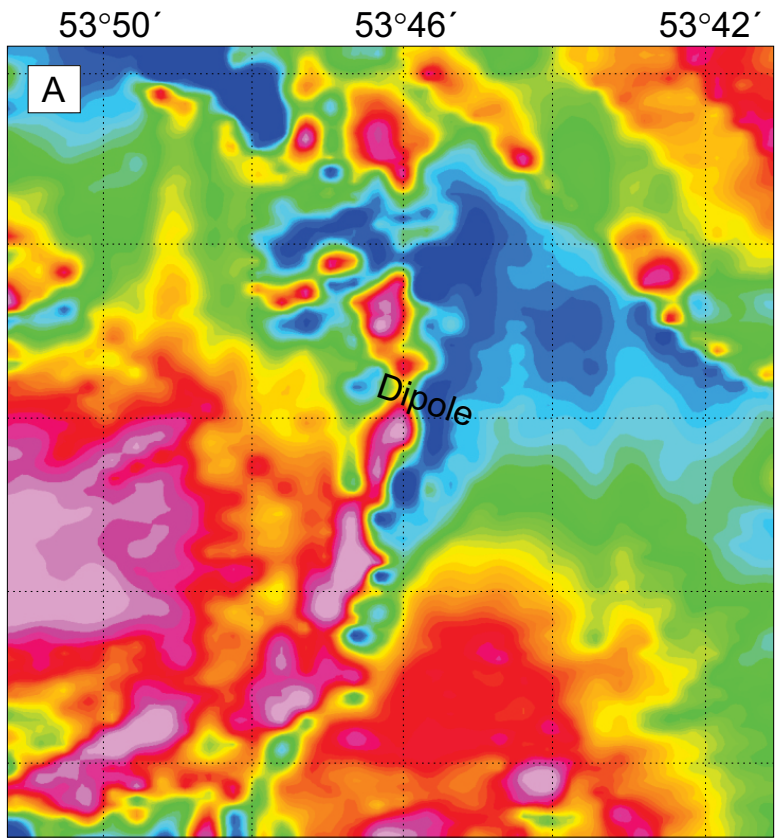

Anomalous magnetic field (nT)
$22653 \quad 22751 \quad 22839$

$54^{\circ}$
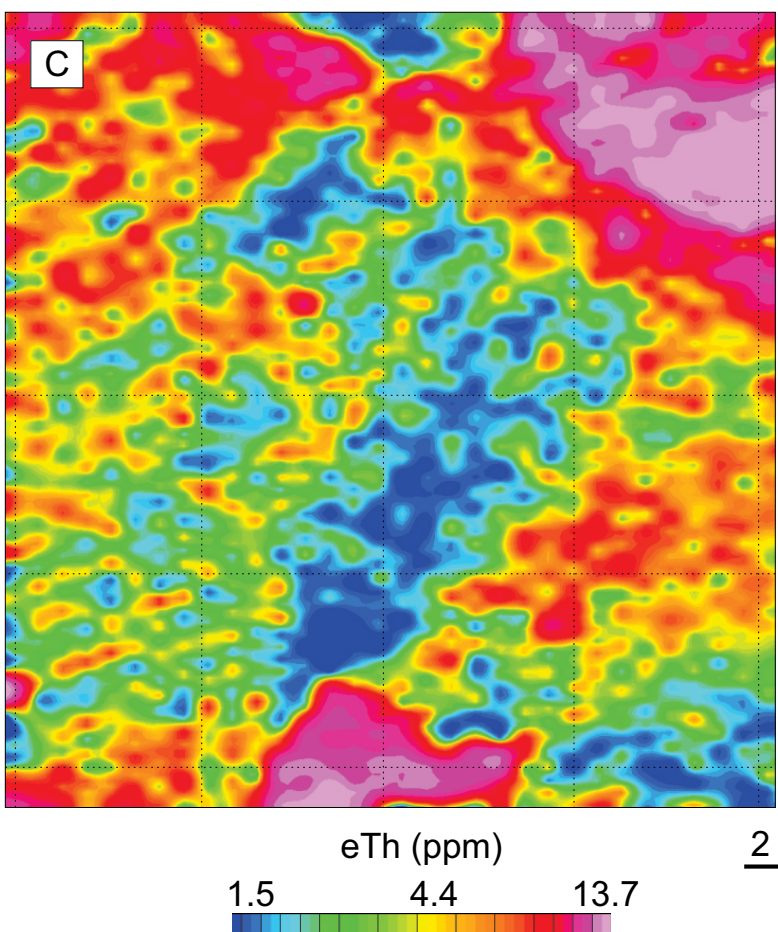
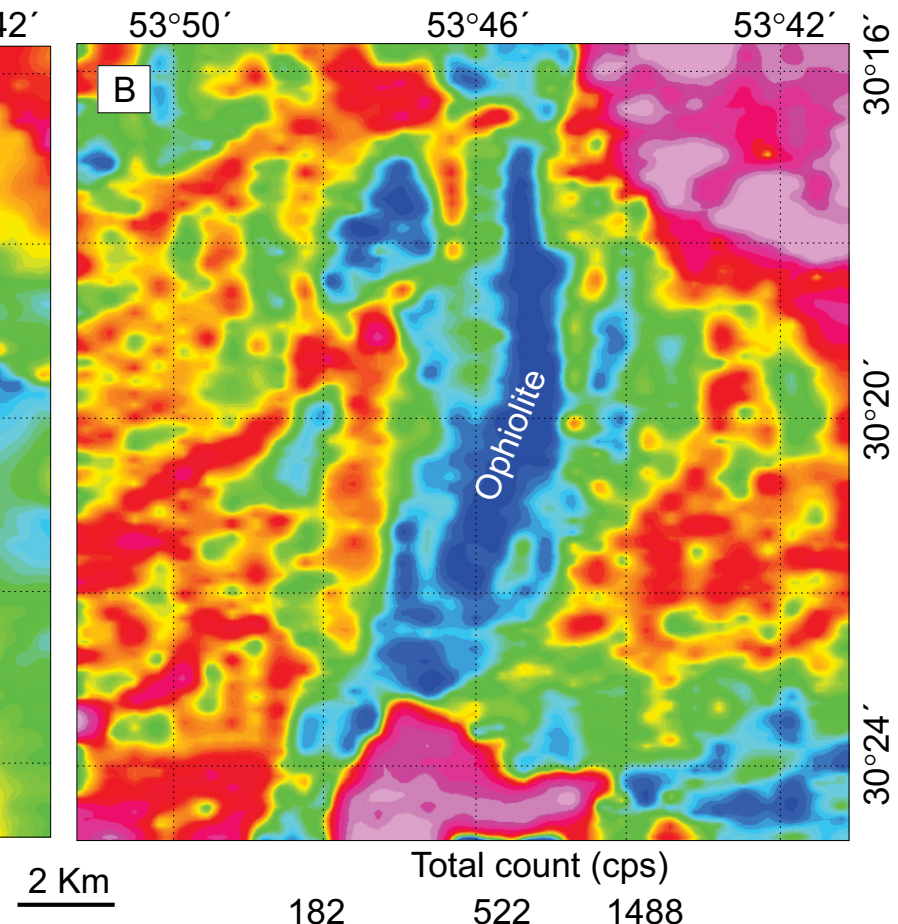

Total count (cps)

182 $522 \quad 1488$

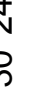




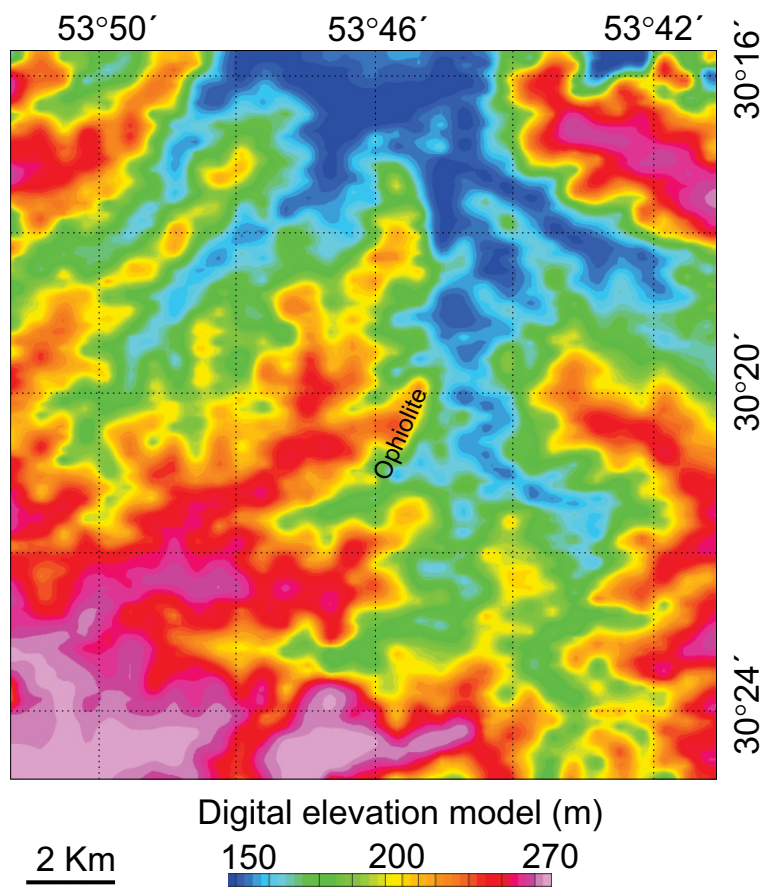

Figure 5. Aerogeophysical maps of ophiolite and neighboring region. (A) Aeromagnetometric map — anomalous magnetic field; dipole position marked. Aerogamaspectrometric map - (B) total count, (C) eTh, and (D) eU. Position of ophiolite indicated in (B). dipping at a high angle to WNW, in common with the other rock types. The rock is medium-grained $(0.5-1.0 \mathrm{~mm})$, dark green to black, and consists of hornblende (50-80 vol.\%), plagioclase (15-45\%), prehnite (1\%), chlorite (1\%), ilmenite $(2 \%)$, and trace zircon.

Under the microscope, hornblende of amphibolite has large light brown cores surrounded by wide light green rims; smaller, homogeneous crystals similar to the rims are abundant and have random orientation in the matrix. Photomicrography of amphibolite (Fig. 7) shows an assemblage of green hornblende altered to blue-green hornblende and plagioclase (andesine-oligoclase) altered to oligoclase and albite. The two generations of minerals mark metamorphic events M1 and M2 (Fig. 12), also registered in all other studied samples.

Plagioclase occurs as large $(0.5-1.0 \mathrm{~mm})$ crystals and in abundant small $(0.05 \mathrm{~mm})$ crystals in the matrix. The quantitative compositional map of a $600 \times 500 \mu \mathrm{m}$ area selected in the amphibolite (Figs. 8A-8F) displays varied zoning in hornblende. All zones have similar Ca content, but $\mathrm{Al}, \mathrm{Fe}, \mathrm{Ti}$ are low in the mantle, whereas $\mathrm{Mg}$ is high in the rim. Ti is higher in the core than rim. Hornblende zoning is barely visible in BSE images (Figs. 8F, 9A and 9B). Prehnite forms a fine-grained mat with plagioclase and chlorite (arrow in Fig. 8F). Prehnite (Fig. 8) is
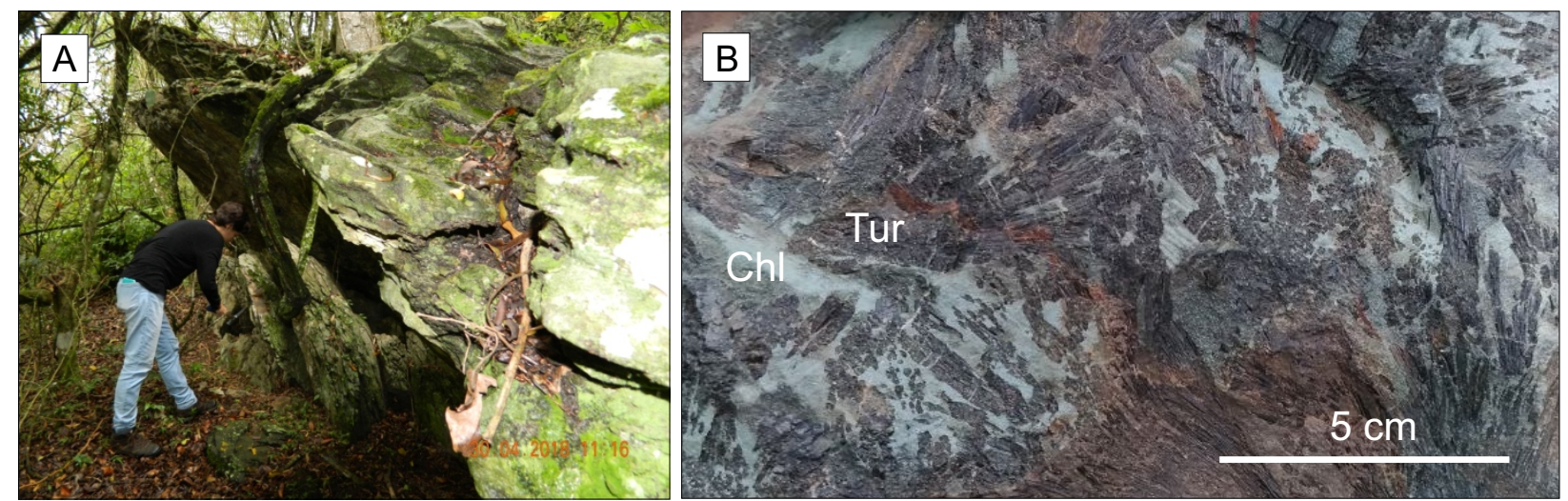

Figure 6. Field photos. (A) Chromite-talc-magnesite granofels; view to south; rock dips $70^{\circ} \mathrm{NNW}$; sample BO 13 collected from this outcrop; (B) Tourmalinite sample BO19, showing tourmaline and chlorite.
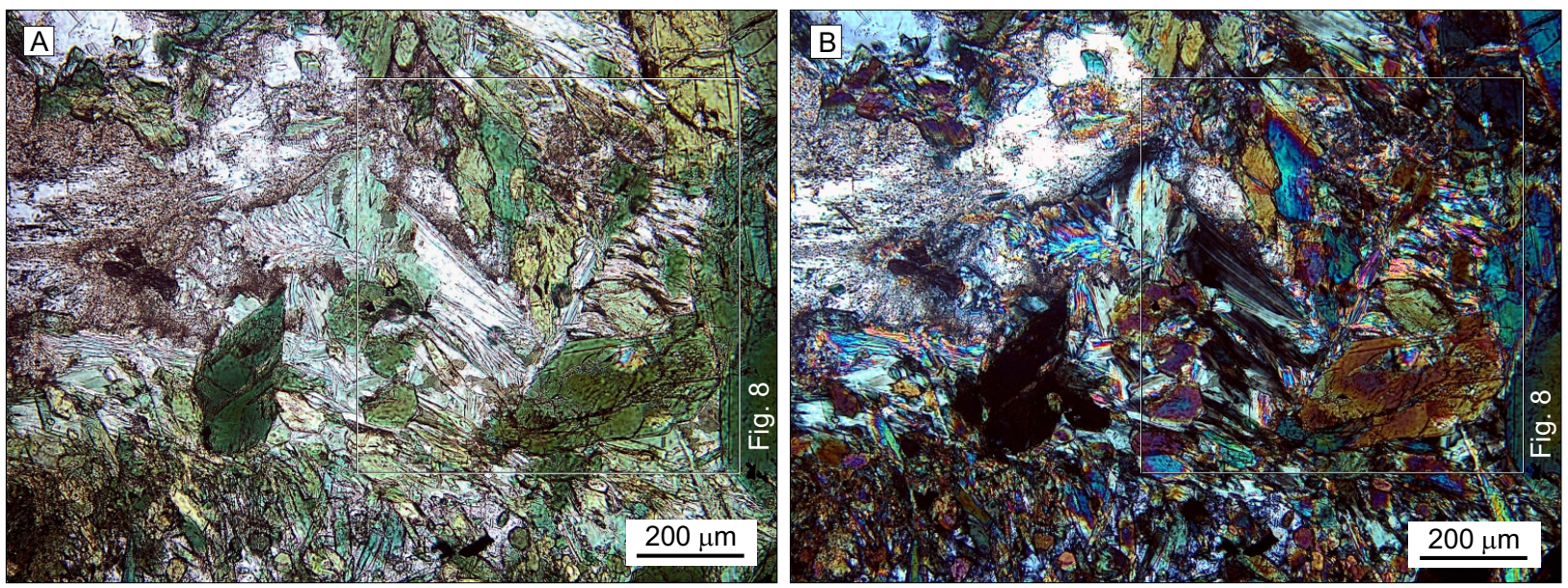

Figure 7. Photomicrographs of amphibolite, sample C3P2. Position of Figure 8 indicated. (A) Plane-polarized light and (B) crossed nicols. 

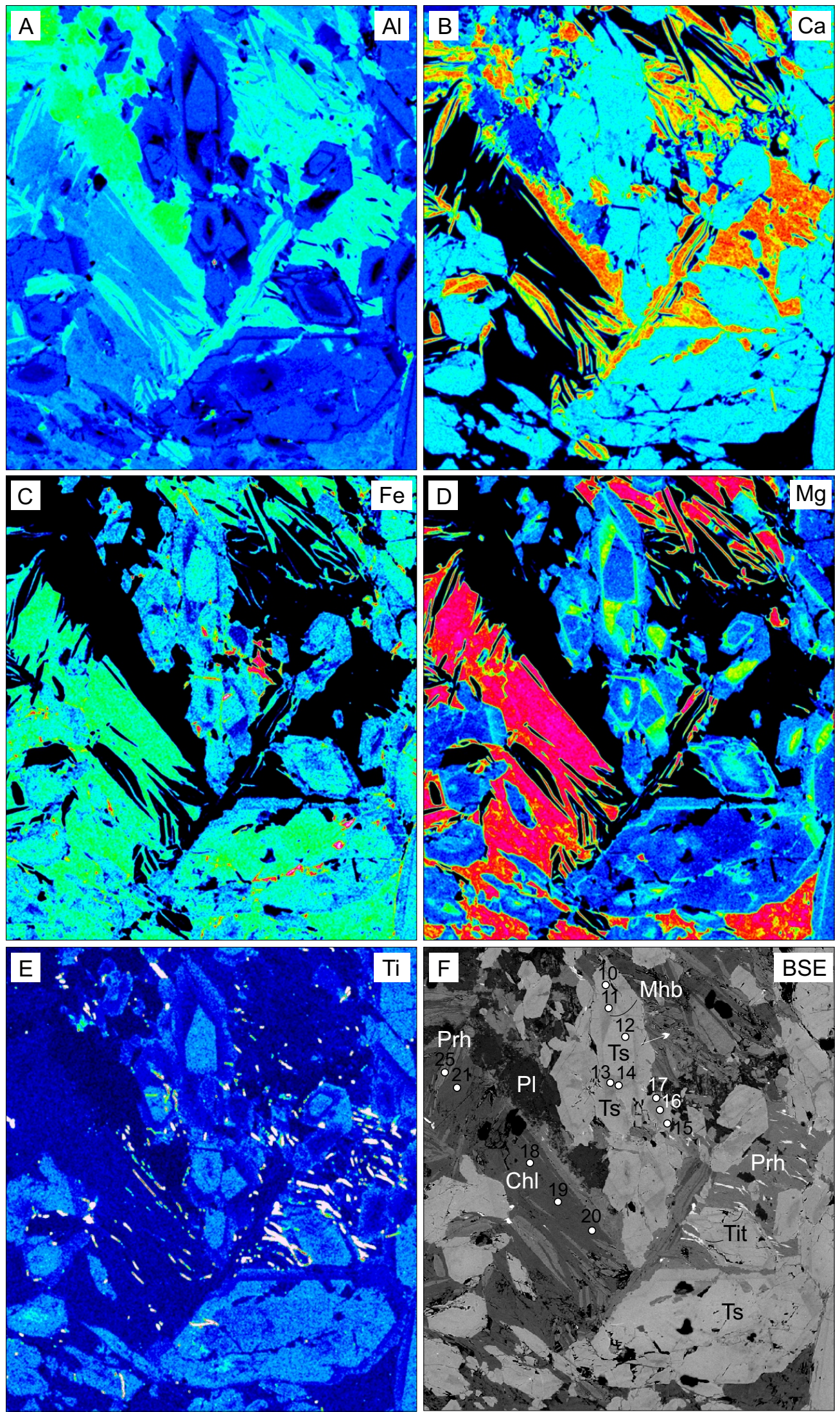

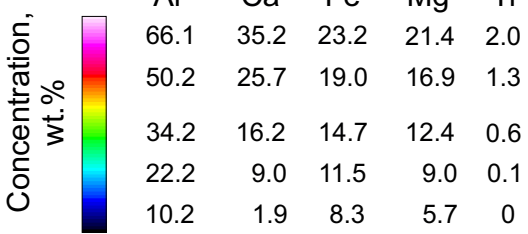

Figure 8. Characteristic X-ray maps and back-scattered electron image of amphibolite within ophiolite, sample C3P2. Position of EPMA analytical spots indicated in $(\mathrm{F})$. 

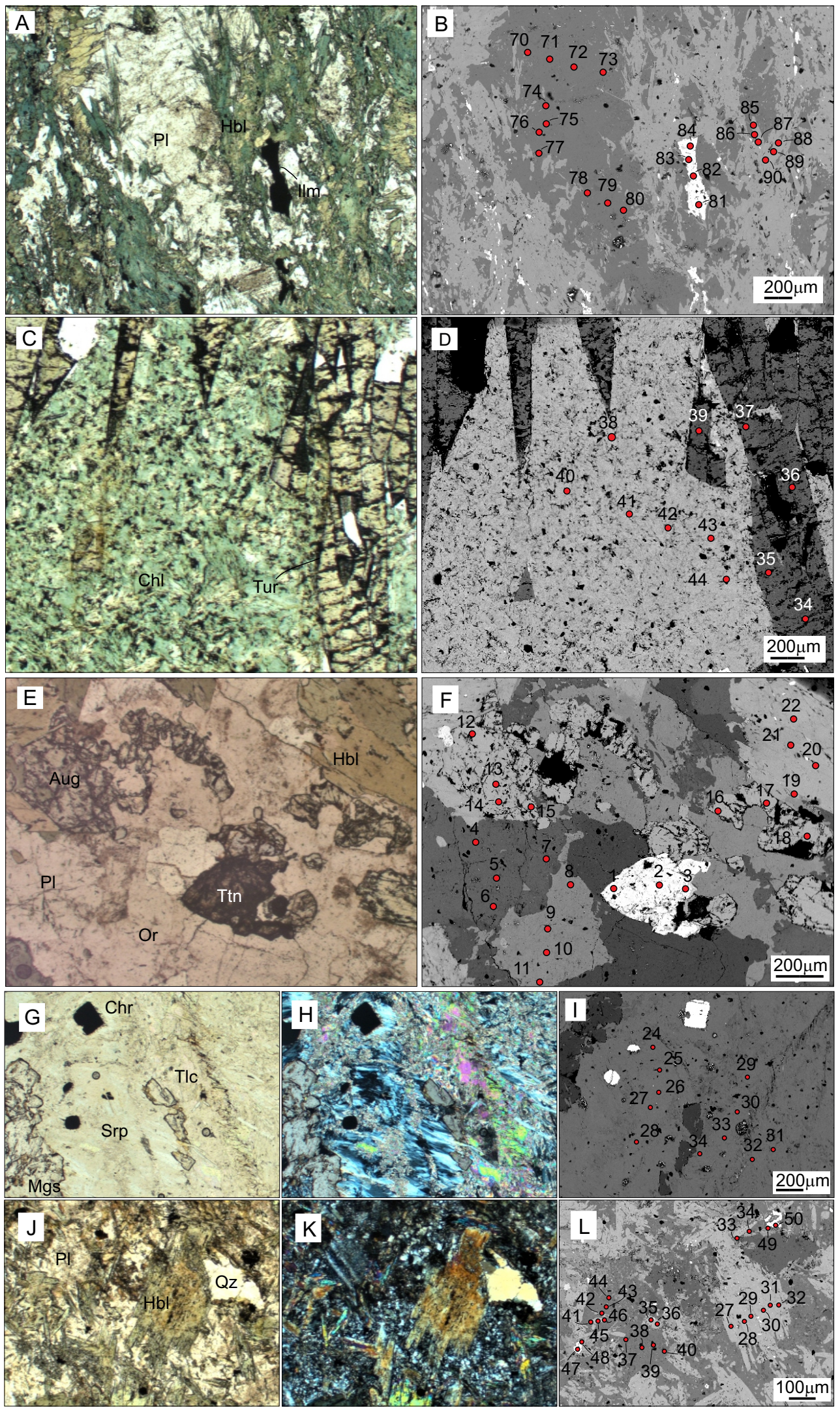

Figure 9. (A) Optical (plane-polarized light) and (B) back-scattered electron (BSE) image of amphibolite, sample C3P2. (C) Optical (planepolarized light) and (D) BSE image of tourmalinite, sample BO19, displaying tourmaline and chlorite; (E) optical (plane-polarized light) and (F) BSE image of Capivaras deformed diorite, sample C3P17; (G) Optical (plane-polarized light), (H) optical (crossed nicols), (I) BSE image of chromite-talc-magnesite granofels located in Figure 3C, sample C3P10; (J) Optical (plane-polarized light), (K) optical (crossed nicols), and (L) BSE image of metavolcanoclastic rock from Campestre Formation, sample C3P4. Points analyzed by EPMA located in BSE images (B, D, F, I, and L). In (A), elongated, ragged hornblende shows pleochroism in green to bluish green (ng) and light brown (np); plagioclase is unzoned and mostly interspersed with hornblende; opaque mineral is present. In (C), unzoned, light yellowish grey tourmaline is associated with light green chlorite. Image (E) shows mineral association of hornblende, clinopyroxene, plagioclase and titanite. Images (G and $\mathrm{H}$ ) document the association of $\mathrm{Cr}$-spinel, talc, magnesite, serpentine. In $(\mathrm{J})$, hornblende displays light brown core and bluish green rim, homogeneous but cloudy plagioclase; in $(\mathrm{K})$, plagioclase is twinned and large $(200 \mu \mathrm{m})$ and small $(5-10 \mu \mathrm{m})$ quartz crystals are present. 

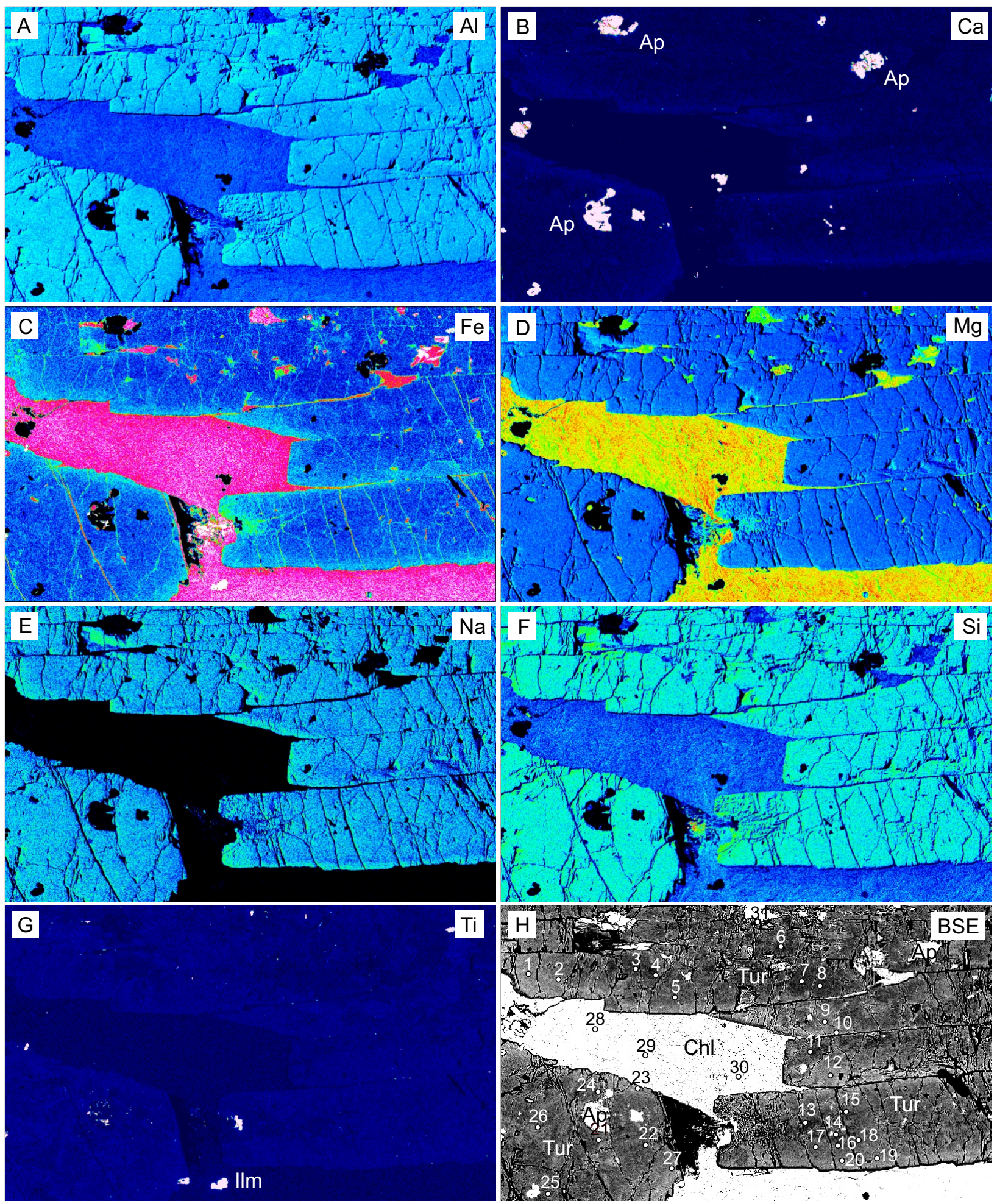

Concentration, wt.\%

$\begin{array}{ccccccc}\mathrm{Al} & \mathrm{Ca} & \mathrm{Fe} & \mathrm{Mg} & \mathrm{Na} & \mathrm{Si} & \mathrm{Ti} \\ 77.5 & 16.8 & 15.6 & 21.0 & 4.2 & 56.1 & 4.4 \\ 58.8 & 12.6 & 12.2 & 16.3 & 3.2 & 45.5 & 3.2 \\ 40.0 & 8.5 & 8.7 & 11.6 & 2.2 & 34.9 & 2.0 \\ 27.5 & 5.7 & 6.4 & 8.4 & 1.6 & 27.8 & 1.3 \\ 15.1 & 2.9 & 4.1 & 5.3 & 0.9 & 20.8 & 0.5\end{array}$

$500 \mu \mathrm{m}$

Figure 10. Characteristic X-ray maps and back-scattered electron (BSE) image of tourmaline, tourmalinite, sample BO19 (mount 2). Two zones are cores poor in $\mathrm{Ca}, \mathrm{Fe}$, Ti and low in BSE and rims enriched in $\mathrm{Ca}, \mathrm{Fe}$, Ti and brighter in BSE. Chlorite poorer in Fe in core than rim of filled fracture. Position of EPMA analytical spots indicated in $(\mathrm{H})$. 
located at the contact of chlorite and plagioclase with patchy contact with plagioclase and some fine protrusions into chlorite. Small (5-100 $\mu \mathrm{m}$ long) titanite crystals are numerous.

Deformed diorite has dominant oligoclase and abundant orthoclase. Magnesiohornblende from the deformed diorite is homogeneous in Si but has variable Mg\# (Fig. 13).

In the metavolcanoclastic rock, nearly all compositions are andesine. Hornblende in metavolcanoclastic rock is chemically zoned from tschermakite (Hbl1) to magnesiohornblende ( $\mathrm{Hbl} 2)$. Hbl2 occurs either as a mantle between core and apparent rim on $\mathrm{Hbll}$ or as patchy alteration portions anywhere within $\mathrm{Hbll}$ and also as homogeneous small crystals. Magnesiohornblende has variable compositions in two different fields.

Massive tourmalinite is dark nearly black with light grey patches of chlorite and displays no apparent foliation or lineation. Tourmaline is dravite (Figs. 14A and 14B) and is restricted to tourmalinite forming boudins contained in metaserpentinite, close $(5 \mathrm{~m})$ to chromite-talc granofels. Crystal zoning seen in compositional maps (Figs. 9C, 9D and 10) is irregular from core to rim and displays increase in $\mathrm{Ca}, \mathrm{Fe}, \mathrm{Al}, \mathrm{Na}$, Ti, and BSE intensity (lighter grey) in narrow
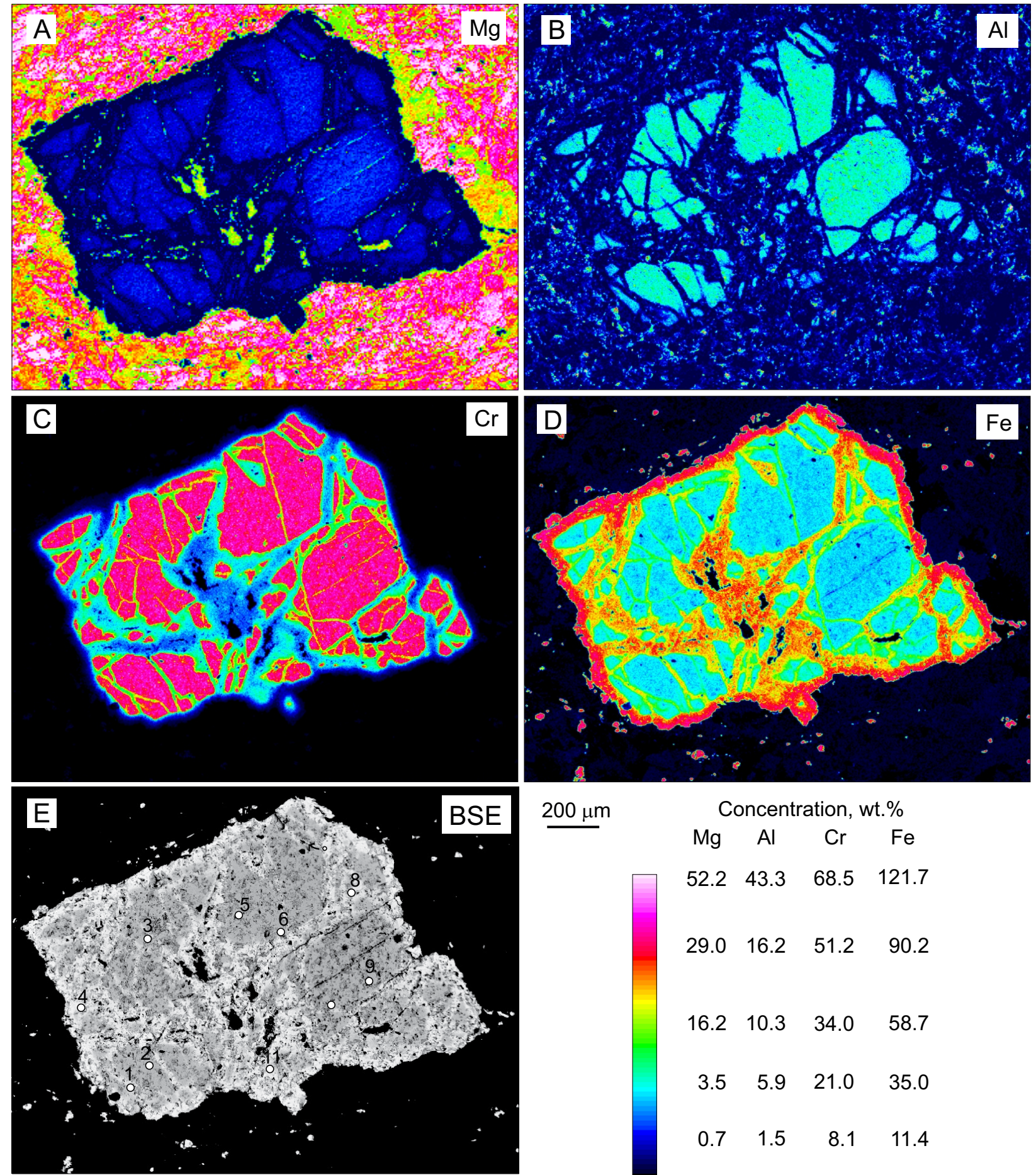

Concentration, wt.\%

$\begin{array}{llll}\mathrm{Mg} \quad \mathrm{Al} & \mathrm{Cr} & \mathrm{Fe}\end{array}$

$\begin{array}{llll}52.2 & 43.3 & 68.5 & 121.7\end{array}$

$\begin{array}{llll}29.0 & 16.2 & 51.2 & 90.2\end{array}$

$\begin{array}{llll}16.2 & 10.3 & 34.0 & 58.7\end{array}$

$\begin{array}{llll}3.5 & 5.9 & 21.0 & 35.0\end{array}$

$\begin{array}{llll}0.7 & 1.5 & 8.1 & 11.4\end{array}$

Figure 11. Characteristic X-ray maps and back-scattered electron image of chromite, chromite-talc-magnesite granofels, sample BO13. Large, homogeneous chromite core portions crossed and margined by magnetite. 
rims. This compositional variation corresponds to homogeneous cores and narrow rims enriched in $\mathrm{Ca}, \mathrm{Fe}, \mathrm{Na}$, and $\mathrm{Ti}$. As a result, BSE images of rims are brighter gray than cores. Associated chlorite shows diffuse zoning, with decrease in $\mathrm{Fe}$ toward rims that are in direct contact with $\mathrm{Fe}$-enriched dravite rim. Minor minerals included in dravite are apatite $(100-200 \mu \mathrm{m})$ and ilmenite $(100 \mu \mathrm{m})$. Few fractures present in dravite are filled with chlorite.

Several additional minerals from the studied rocks yield significant information. Metasomatic rocks - chromite-talc-magnesite granofels and chloritite - had Cr-spinel (picotite, chromite, and magnetite) studied (Fig. 15). Cr-spinel cores are homogeneous, but rims and fractures are strongly altered to magnetite (Fig. 11). Chlorite (Fig. 10) occurs in variable sizes $(20-500 \mu \mathrm{m})$ and has variable contents of $\mathrm{Al}, \mathrm{Mg}$, and Ti. Chlorite is clinochlore in chloritite but ripidolite in amphibolite and tourmalinite (Fig. 16).

Serpentinite displays common jackstraw texture illustrating the lower amphibolite facies mineral association olivine + talc + chlorite (Hartmann et al. 1987), superposed by intense serpentinization. Whole-rock chemical analyses of serpentinite display rare earth elements (REE) composition with low content of medium and heavy REE as an

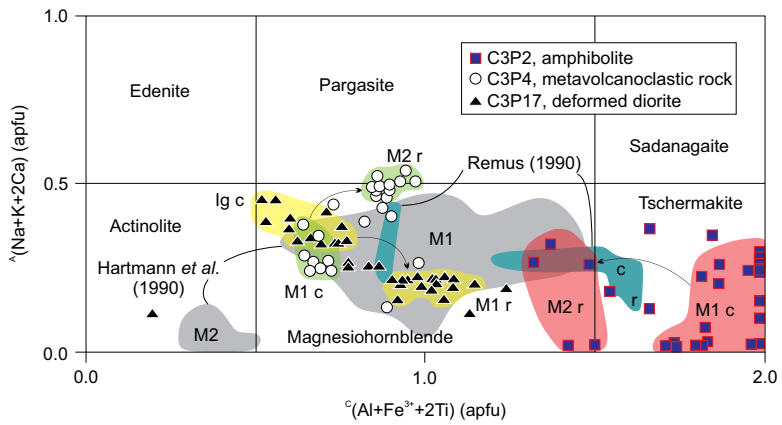

Figure 12. Chemical classification diagram of hornblende (based on Hawthorne et al. 2012) from three studied samples. Compositional fields of published hornblende compositions from São Gabriel terrane also shown. A few tschermakite analyses plotted above the 2.0 apfu limit, above the line. M1 and M2 metamorphic events marked from core (c) and rim (r) of crystals. Core (c) and rim ( $r$ ) of crystals from one amphibolite sample from Remus (1990) (Cambaizinho ophiolite) indicated.

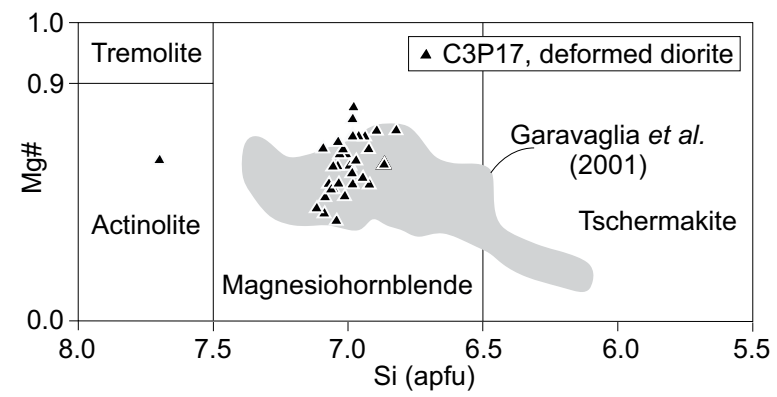

Figure 13. Chemical classification diagram of hornblende from sample C3P17 (deformed diorite) compared with compositions of Capivaras diorite from Garavaglia et al. (2002). exploratory result. Nevertheless, the REE contents are very low. Chromite-talc-magnesite granofels (Suppl. Tab. A16) has low $\mathrm{SiO}_{2}$ and $\mathrm{Al}_{2} \mathrm{O}_{3}$; high $\mathrm{Cr}_{2} \mathrm{O}_{3}$ and $\mathrm{Ni}$ support origin from altered serpentinite.

\section{DISCUSSION}

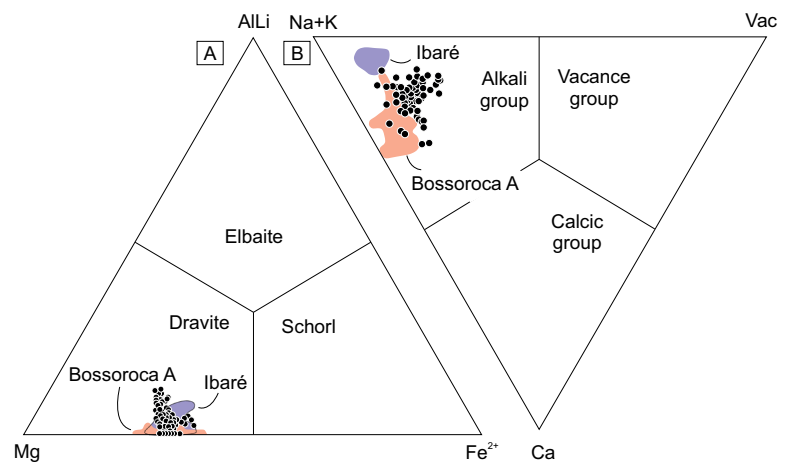

Figure 14. Chemical classification diagrams of tourmaline, tourmalinite sample BO19. Tourmaline A from Hartmann et al. (2019) occurs within same studied area.

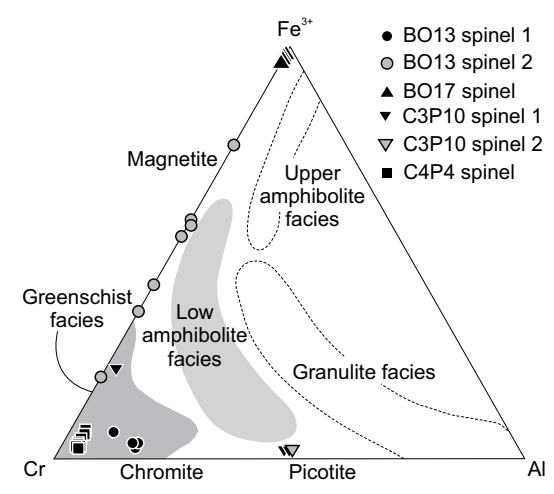

Figure 15. Chemical classification diagram of $\mathrm{Cr}$-spinel from Bossoroca ophiolite. Compositional fields of metamorphosed spinel shown (modified from Abdel-Karim and El-Shafei 2018). Composition of minerals indicated.

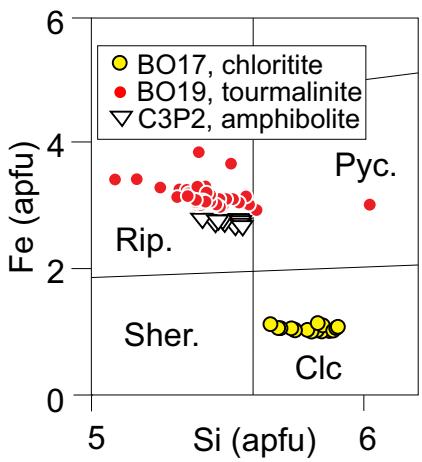

Rip.: ripidolite; Clc: clinochlore; Pyc.: picnochlorite; Sher.: sheridinite. Source: based on Hey (1954)

Figure 16. Chemical classification diagram of chlorite. 
Multiproxy evaluation of the Bossoroca ophiolite in the Campestre traverse resulted in advanced knowledge of field relationships and mineralogy of metasomatic and associated rocks. Aeromagnetometry and aerogamaspectrometry of the studied ophiolite better define the distribution of mafic and ultramafic rocks in the geological environment of oceanic island-arc. The association with serpentinite and occurrence of serpentine and chromite in the granofels testify to the origin from altered serpentinite of depleted mantle geochemistry. Granofels is known to contain significant gold deposits in the Arabian-Nubian Shield (NE Africa).

Two metamorphic events occurred in the ophiolite, due to the structure and composition of hornblende and the variable composition of plagioclase (Fig. 17) of amphibolite. In the ophiolite, both events occurred under similar $\mathrm{P}$ and $\mathrm{T}$ conditions (Fig. 18). Tschermakite was the first hornblende (Hbl1) to crystallize during metamorphism M1, succeeded by magnesium hornblende ( $\mathrm{Hbl} 2$ ) during M2. Hbl2 formed by extensive recrystallization of $\mathrm{Hbll}$ in different positions of the crystals. Ti in hornblende can be used as an indicator of metamorphic facies. Ti $=0.5-1.0 \mathrm{apfu}$ is characteristic of hornblende formed in lower amphibolite facies (Raase 1974, Holland and Richardson 1979), e.g., Bossoroca ophiolite.

The Capivaras diorite infrastructure has magmatic hornblende in the cores and metamorphic hornblende in the rims. A volcanoclastic rock from the superstructure Campestre Formation has two comparable hornblende compositions in cores and rims. The olivine + talc association in metaserpentinite indicates lower amphibolite facies metamorphism, in agreement with the grade of metamorphism of the infrastructure deformed diorite and superstructure metavolcanoclastic rock. This metamorphic event M1 occurred during the obduction of Bossoroca ophiolite onto an oceanic island arc.

In amphibolite, prehnite stabilization was achieved by $\mathrm{Ca}$ availability in host titanite. Longer $(50 \mu \mathrm{m})$ and wider $(5 \mu \mathrm{m})$ titanite crystals are apparent in BSE image (Fig. 8F); shorter

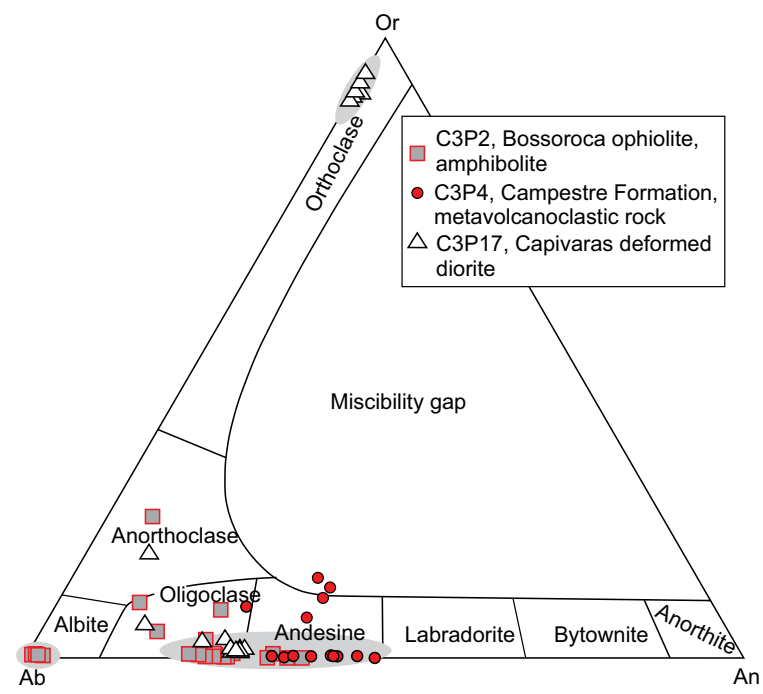

Figure 17. Chemical classification diagram of feldspar. Main compositional fields marked in grey elipses.
$(<50 \mu \mathrm{m})$ and narrower $(<5 \mu \mathrm{m})$ crystals only show in $\mathrm{Ti}$ image. Titanite formed within prehnite crystals during reaction of chlorite with andesine-oligoclase, obtaining $\mathrm{Ti}, \mathrm{Mg}$, and $\mathrm{Fe}$ from chlorite and $\mathrm{Ca}, \mathrm{Al}$ from andesine-oligoclase. $\mathrm{Ca}$ is more mobile and moved from plagioclase into the altered chlorite crystal to form titanite; in totally altered chlorite, titanite contained within prehnite is larger than titanite enclosed in altered chlorite.

Chromite composition is compatible with lower amphibolite facies metamorphism. The tourmalinite is similar to rocks described by Hartmann et al. (2019) and Arena et al. (2019), because of assemblage with clinochlore and dravite composition. Metamorphic tourmaline is common in amphibolite facies rocks, although the mineral may form in the full range of metamorphic conditions, notably low and medium grade metamorphism (Henry and Dutrow 1996, Berryman et al. 2016, 2017, Zheng et al. 2019). These rocks are interpreted as formed in oceanic crust fumaroles, since tourmaline is known to be formed in the oceanic realm (Slack et al. 1998, van Hinsberg et al. 2011).

Evolution of the mantellic portion of ophiolite originated in the depleted mantle, as indicated by low contents of REE (Fig. 19). The Bossoroca ophiolite has metasomatic rocks formed in the northern part of the ocean floor, constraining early juvenile evolution of Brasiliano Orogen in lower amphibolite facies conditions of obduction onto an island arc.

\section{CONCLUSIONS}

Our focus on the northern Bossoroca ophiolite, Tonian São Gabriel terrane with multi-techniques resulted in significant conclusions. Oceanic rocks are prominent - chromite-talc-magnesite granofels, amphibolite and tourmalinite, associated with mantelic rocks - serpentinite. Low

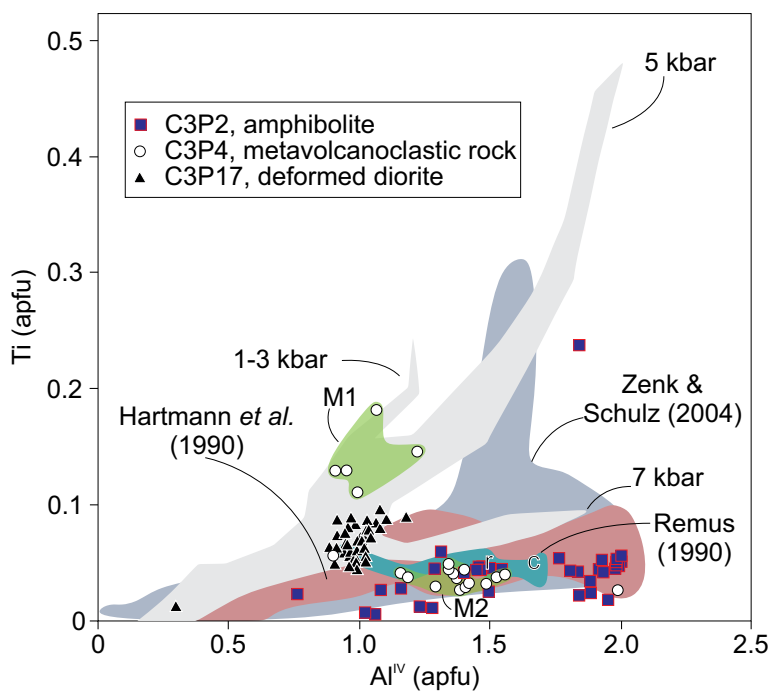

Figure 18. Chemical composition of hornblende $\left(\mathrm{Al}^{\mathrm{IV}}\right)$ vs. Ti (apfu) from three studied samples in Zenk and Schulz (2004) diagram, indicating medium pressure metamorphic conditions; M1 in Campestre Formation is suggestive of lower pressure. Published hornblende compositions from São Gabriel terrane also shown. Core (c) and rim (r) of crystals from one amphibolite sample from Remus (1990) (Cambaizinho ophiolite) indicated. 


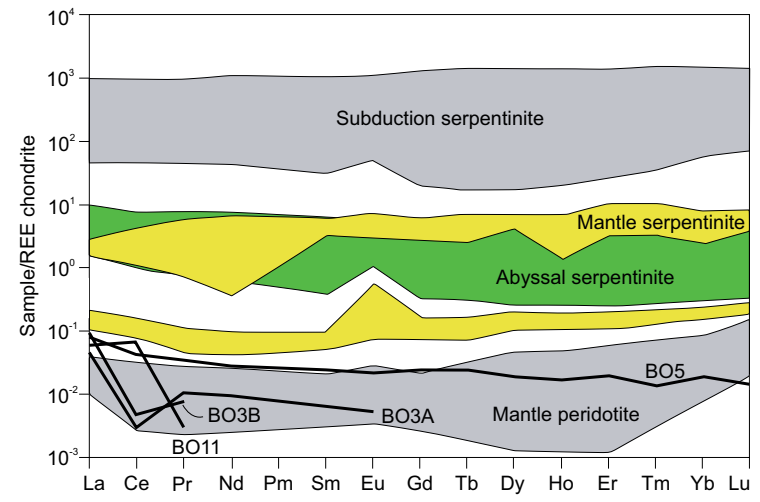

Figure 19. Reconnaissance rare earth elements diagram of studied serpentinite samples (chondrite from Boynton 1984) suggestive of similarity with mantle, abyssal peridotite. Mantellic compositional fields from Arena et al. (2018; their Fig. 6B).

aeromagnetometric and gamaspectrometric signals support delimitation of mafic and ultramafic rocks from the ophiolite. Two metamorphic events are recognized - M1 in the low amphibolite facies (ocean-floor metamorphism), widespread in all rock types, and M2 either in low amphibolite facies (obduction-related) or in prehnite facies, both regional metamorphism. Host island arc rocks (Cambaí Complex infrastructure and Campestre Formation superstructure) underwent comparable M1 and M2 metamorphic conditions. The Bossoroca ophiolite evolved from oceanic crust to obduction on island-arc, mostly in low-amphibolite facies metamorphic conditions.

\section{ACKNOWLEDGMENTS}

We acknowledge support in the field by Tiara Cerva Alves, Mariana Werle, and Vítor Casagrande Dias. Amanda J. Massuda thanks Conselho Nacional do Desenvolvimento Científico e Tecnológico (CNPq) - Brazilian Government for MS scholarship. This study led to the Master of Science degree of Massuda at Programa de Pós-Graduação em Geociências, Universidade Federal do Rio Grande do Sul. Hartmann received systematic financial support, research scholarship, and grant from CNPq. Queiroga is a fellow of CNPq and acknowledges its support. The authors are also grateful to the Laboratório de Microscopia e Microanálises (LMIc) of UFOP, a member of FAPEMIGsupported Microscopy and Microanalysis Network of Minas Gerais. We thank Geological Survey of Brazil (CPRM) for the aerogeophysical data. Fabrício Caxito and one anonymous reviewer made significant contributions to the improvement of the article.

\section{ARTICLE INFORMATION}

Manuscript ID: 20190120. Received on: 11/11/2019. Approved on: 06/25/2020.

All authors contributed to the article. A.M. wrote the first draft of the manuscript and prepared all figures and tables; L.H. supervised the scientific activity and revised the manuscript, including the English writing; G.Q. supervised EPMA analyses of the minerals; M.C. operated the EPMA and made analyses with quality control; C.L. and J.S. made the aerogeophysical maps and supported the interpretation.

Competing interests: The authors declare no competing interests.

\section{REFERENCES}

Abdel-Karim A.-A.M., El-Shafei S.A. 2018. Mineralogy and chemical aspects of some ophiolitic metaultramafics, central Eastern Desert, Egypt: Evidences from chromites, sulphides and gangues. Geological Journal, 53(2):580-599. https://doi.org/10.1002/gj.2914

Amaral L., Caxito F.A., Pedrosa-Soares A.C., Queiroga G., Babinski M., Trindade R., Lana C., Chemale F. 2020. The Ribeirão da Folha ophiolitebearing accretionary wedge (Araçuaí orogen, SE Brazil): New data for Cryogenian plagiogranite and metasedimentary rocks. Precambrian Research, 336:105522. https://doi.org/10.1016/j.precamres.2019.105522

Arena K.R., Hartmann L.A., Lana C. 2016. Evolution of Neoproterozoic ophiolites from the southern Brasiliano Orogen revealed by zircon U-PbHf isotopes and geochemistry. Precambrian Research, 285:299-314. https:// doi.org/10.1016/j.precamres.2016.09.014

Arena K.R., Hartmann L.A., Lana C. 2017. Tonian emplacement of ophiolites in the southern Brasiliano Orogen delimited by U-Pb-Hf isotopes of zircon from metasomatites. Gondwana Research, 49:296-332. https://doi. org/10.1016/j.gr.2017.05.018

Arena K.R., Hartmann L.A., Lana C. 2018. U-Pb-Hf isotopes and trace elements of metasomatic zircon delimit the evolution of the neoproterozoic Capané ophiolite in the southern Brasiliano Orogen. International Geology Review, 60(7):911-928. https://doi.org/10.1080/0 0206814.2017 .1355269

Arena K.R., Hartmann L.A., Lana C., Queiroga G.N., Castro M.P. 2019. Geochemistryand $\delta^{11}$ B evolution of massivetourmalinefrom the Tonian Ibaré ophiolite, southern Brasiliano Orogen. Annals Brazilian Academy of Sciences, 92(1):e20180193. https://doi.org/10.1590/0001-3765202020180193
Azer M.K., Gahlan H.A., Asimow P.D., Mubarak H.S., Al-Kahtany K.N. 2019. Multiple stages of carbonation and element redistribution during formation of ultramafic-hosted magnesite in Neoproterozoic Ophiolites of the Arabian-Nubian Shield, Egypt. The Journal of Geology, 127(1):81-107. https://doi.org/10.1086/700652

Babinski M., Chemale Jr. F, Hartmann L.A., Van Schmus W.R., Silva L.C. 1996. Juvenile accretion at 750-700 Ma in southern Brazil. Geology, 24(5):439-442. https://doi.org/10.1130/0091-7613(1996)024\%3C0439 :JAAMIS\%3E2.3.CO;2

Barriga F., Fyfe W.S. 1983. Development of rodingite in basaltic rocks in serpentinites, East Liguria, Italy. Contributions to Mineralogy and Petrology, 84:146-151. https://doi.org/10.1007/BF00371281

Barros L.D., Gorayeb P.S.S. 2019. Serra do Tapa Ophiolite Suite - Araguaia Belt: Geological characterization and Neoproterozoic evolution (centralnorthern Brazil). Journal of South American Earth Sciences, 96:102323. https://doi.org/10.1016/j.jsames.2019.102323

Basei M.A.S., Frimmel H.E., Campos Neto M.C., Ganade de Araújo C.E., Castro N.A., Passarelli C.R. 2018. The Tectonic History of the Southern Adamastor Ocean Based on a Correlation of the Kaoko and Dom Feliciano Belts. In: Siegesmund S., Basei M.A.S., Oyhantçabal P., Oriolo, S. (Eds.), Geology of Southwest Gondwana, Regional Geology Reviews. Berlin: Springer International Publishing, p. 63-85.

Berryman E.J., Kutzschbach M., Trumbull R.B., Meixner A., van Hinsberg V., Kasemann S.A., Franz G. 2017. Tourmaline as a petrogenetic indicator in the Pfitsch Formation, Western Tauern Window, Eastern Alps. Lithos, 284285:138-155. https://doi.org/10.1016/j.lithos.2017.04.008 
Berryman E.J., Wunder B., Rhede D., Schettler G., Franz G., Heinrich W. 2016. P-T-X controls on $\mathrm{Ca}$ and $\mathrm{Na}$ distribution between $\mathrm{Mg}-\mathrm{Al}$ tourmaline and fluid. Contributions to Mineralogy and Petrology, 171:31. https://doi.org/10.1007/s00410-016-1246-8

Bologna M.S., Dragone G.N., Muzio R., Peel E., Nuñez-Demarco P., Ussami N. 2019. Electrical structure of the lithosphere from Rio de la Plata Craton to Paraná Basin: Amalgamation of cratonic and refertilized lithospheres in SW Gondwanaland. Tectonics, 38(1):77-94. https://doi. org/10.1029/2018TC005148

Boynton W.V. 1984. Cosmochemistry of the rare earth elements; meteorite studies. In: Henderson P. (Ed.), Rare earth element geochemistry. Amsterdam: Elsevier, p. 63-114.

Caxito F., Uhlein A., Stevenson R., Uhlein G.J. 2014. Neoproterozoic oceanic crust remnants in northeast Brazil. Geology, 42(5):387-390. https://doi.org/10.1130/G35479.1

Cerva-Alves T., Hartmann L.A., Remus M.V.D., Lana C. 2020. Integrated ophiolite and arc evolution, southern Brasiliano Orogen. Precambrian Research, 341:105648. https://doi.org/10.1016/j.precamres.2020.105648

Dubińska E., Bylina P., Kozłowski A., Dörr W., Nejbert K., Schastok J., Kulicki C. 2004. U-Pb dating of serpentinization - hydrothermal zircon from a metasomatic rodingite shell (Sudetic ophiolite, SW Poland). Chemical Geology, 203(3-4):183-203.

Fernandes L.A.D., Menegat R., Costa A.F.U., Koester E., Porcher C.C., Tommasi A., Kraemer G., Ramgrab G.E., Camozzato E. 1995. Evolução tectônica do Cinturão Dom Feliciano no Escudo Sul-Rio-Grandense: Parte II - Uma contribuição a partir das assinaturas geofísicas. Revista Brasileira de Geociências, 25(4):375-384.

Garavaglia L., Bitencourt M.F., Nardi L.V.S. 2002. Cumulatic diorites related to post-collisional, Brasiliano Pan-African mafic magmatism in the Vila Nova Belt, southern Brazil. Gondwana Research, 5(2):519-534. https://doi. org/10.1016/S1342-937X(05)70740-1

Goñi J.C., Goso H., Issler R.S. 1962. Estratigrafia e geologia economica do Pré-Cambriano e Eo-Paleozóico Uruguaio e Sul-Riograndense. Avulso da Escola de Geologia da UFRGS, (3):1-105.

Gubert M.L., Philipp R.P., Basei M.A.S. 2016. The Bossoroca Complex, São Gabriel Terrane, Dom Feliciano Belt, southernmost Brazil. U-Pb geochronology and tectonic implications for the neoproterozoic São Gabriel Arc. Journal of South American Earth Sciences, 70:1-17. https://doi. org/10.1016/j.jsames.2016.04.006

Hartmann L.A., Chemale Jr. F., Philipp R.P. 2007. Evolução Geotectônica do Rio Grande do Sul no Pré-Cambriano. In: Iannuzzi R., Frantz J.C. (Eds.). 50 anos de Geologia. Porto Alegre: Instituto de Geociências, p. 97-123.

Hartmann L.A., Delgado I.M. 2001. Cratons and orogenic belts of the Brazilian Shield and their contained gold deposits. Mineralium Deposita, 36:207-217. https://doi.org/10.1007/s001260100175

Hartmann L.A., Lopes W.R., Savian J.F. 2016. Integrated evaluation of the geology, aerogammaspectrometry and aeromagnetometry of the SulRiograndense Shield, southernmost Brazil. International Geology Review, 88(1):75-92. https://doi.org/10.1590/0001-3765201520140495

Hartmann L.A., Nardi L.V.S., Formoso M.L.L., Remus M.V.D., Lima E.F., Mexias A.S. 1999. Magmatism and metallogeny in the crustal evolution of Rio Grande do Sul shield, Brazil. Pesquisas em Geociências, 26(2):45-63. https://doi.org/10.22456/1807-9806.21123

Hartmann L.A., Philipp R.P., Santos J.O.S., McNaughton N.J. 2011. Time frame of 753-680 Ma juvenile accretion during the São Gabriel orogeny, southern Brazil. Gondwana Research, 19(1):84-99. https://doi. org/10.1016/j.gr.2010.05.001

Hartmann L.A., Remus, M.V.D., Koppe J.C. 1987. Distinção entre textura spinifex e arranjos de olivina metamorfica. Revista Brasileira de Geociências, 17(3):302-305.

Hartmann L.A., Werle M., Michelin C.R.L., Lana C., Queiroga G.N., Castro M.P., Arena K.R. 2019. Proto-Adamastor ocean crust (920 Ma) described in Brasiliano Orogen from coetaneous zircon and tourmaline. Geoscience Frontiers, 10(4):1623-1633. https://doi.org/10.1016/j.gsf.2018.09.018

Hawthorne F.C., Oberti R., Harlow G.E., Maresch W.V., Martin R.F., Schumacher J.C., Welch M.D. 2012. IMA report. Nomenclature of the amphibole supergroup. American Mineralogist, 97(11-12):2031-2048. https://doi.org/10.2138/am.2012.4276
Henry D.J., Dutrow B.L. 1996. Metamorphic tourmaline and its petrologic applications. Reviews in Mineralogy, 33(1):503-557.

Hey M.H. 1954. A new review of the chlorite. Mineralogy Magazine, 30(224):277-292. https://doi.org/10.1180/minmag.1954.030.224.01

Hodel F., Trindade R.I.F., Macouin M., Meira V.T., Dantas E.L., Paixão M.A.P., Rospabé M., Castro M.P., Queiroga G.N., Alkmim A.R., Lana C.C. 2019. A Neoproterozoic hyper-extended margin associated with Rodinia's demise and Gondwana's build-up: The Araguaia Belt, central Brazil. Gondwana Research, 66:43-62. https://doi.org/10.1016/j.gr.2018.08.010

Hoerlle G.S., Remus M.V.D., Dani N., Gomes M.E.B., Ronchi L.H. 2019. Evolution of fluorite-mica-feldspar veins: Evidences of a fossil geothermal system in the são Gabriel terrane and consequences for $\mathrm{Pb}-\mathrm{Zn}-\mathrm{Cu}$ metallogeny. Journal of South American Earth Sciences, 92:209-221. https:// doi.org/10.1016/j.jsames.2019.03.006

Holland T.J.B., Richardson S.W. 1979. Amphibole zonation in metabasites as a guide to the evolution of metamorphic conditions. Contributions to Mineralogy and Petrology, 70:143-148. https://doi.org/10.1007/ BF00374442

Koppe J.C., Hartmann L.A. 1990. Geochemistry of the Bossoroca greenstone belt. Southernmost Brazil. Geochimica Brasiliensis, 2(2):167-174.

Koppe J.C., Hartmann L.A., Lisboa P.F.C., Monteiro R.N. 1985. Aspectos geológicos e estratigráficos do Complexo Bossoroca, São Sepé, Rio Grande do Sul. In: Simpósio Sul-Brasileiro de Geologia, 2., Florianópolis. Anais... Florianópolis: SBG, p. 32-36.

Lena L.O.F., Pimentel M.M., Philipp R.P., Armstrong R., Sato K. 2014. The evolution of the Neoproterozoic São Gabriel juvenile terrane, southern Brazil based on high spatial resolution $\mathrm{U}-\mathrm{Pb}$ ages and ${ }^{18} \mathrm{O}$ data from detrital zircons. Precambrian Research, 247:126-138. https://doi.org/10.1016/j. precamres.2014.03.010

Machado N., Koppe J.C., Hartmann L.A. 1990. A Late Proterozoic $\mathrm{U}-\mathrm{Pb}$ age for the Bossoroca Belt, Rio Grande do Sul, Brazil. Journal of South American Earth Sciences, 3(2-3):87-90. https://doi. org/10.1016/0895-9811(90)90021-R

Mattos P.R., Philipp R.P., Mexias A.S., Gomes M.E.B. 2004. Metamorfismo de contato no Complexo Bossoroca, porção SW do Complexo Granítico São Sepé, RS, Brazil. Revista Brasileira de Geociências, 34(1):1-10.

Milligan P.R., Gunn P.J. 1997. Enhancement and presentation of airborne geophysical data. AGSO Journal of Australian Geology and Geophysics, 17(2):63-75.

Nabighian M.N., Grauch V.J.S., Hansen R.O., LaFehr T.R., Li Y., Peirce J.W., Phillips J.D., Ruder M.E. 2005. The historical development of the magnetic method in exploration. Geophysics, 70(6):33-61. https://doi. org/10.1190/1.2133784

Peel E., Bettucci L.S., Basei M.A.S. 2018. Geology and geochronology of Paso del Dragón Complex (northeastern Uruguay): Implications on the evolution of the Dom Feliciano Belt (Western Gondwana). Journal of South American Earth Sciences, 85:250-262. https://doi.org/10.1016/j. jsames.2018.05.009

Philipp R.P., Pimentel M.M., Basei M.A.S. 2018. The Tectonic Evolution of the São Gabriel Terrane, Dom Feliciano Belt, Southern Brazil: The Closure of the Charrua Ocean. In: Siegesmund S., Basei M.A.S., Oyhantçabal P., Oriolo S. (Eds.), Geology of Southwest Gondwana, Regional Geology Reviews. Berlin: Springer International Publishing, p. 243-265.

Queiroga G.N., Pedrosa-Soares A.C., Noce C.M., Alkmim F.F., Pimentel M.M., Dantas E., Martins M., Castañeda C., Suita M.T.F., Prichard F. 2007. Age of the Ribeirão da Folha ophiolite, Araçuaí Orogen: The U-Pb zircon dating of a plagiogranite. Geonomos, 15(1):61-65. https://doi. org/10.18285/geonomos.v15i1.107

Raase P. 1974. A1 and Ti contents of hornblende, indicators of pressure and temperature of regional metamorphism. Contributions to Mineralogy and Petrology, 45(3):231-236. https://doi.org/10.1007/BF00383440

Ramos R.C., Koester E. 2015. Lithogeochemistry of the meta-igneous units from Arroio Grande Ophiolitic Complex, southernmost Brazil. Brazilian Journal of Geology, 45(1):65-78. http://dx.doi.org/10.1590/2317488920 1500010005

Remus M.V.D. 1990. Geologia e Geoquímica do Complexo Cambaizinho, São Gabriel, RS. MSc thesis, Instituto de Geociências, Universidade Federal do Rio Grande do Sul, Porto Alegre, 267 p. 
Remus M.V.D., McNaughton N.J., Hartmann L.A., Koppe J.C., Fletcher I.R., Groves D.I., Pinto V.M. 1999. Gold in the Neoproterozoic juvenile Bossoroca volcanic arc of southernmost Brazil: Isotopic constraints on timing and sources. Journal of South American Earth Sciences, 12(4):349 366. https://doi.org/10.1016/S0895-9811(99)00026-7

Saalmann K., Remus M.V.D., Hartmann L.A. 2006. Tectonic evolution of the Neoproterozoic São Gabriel block, southern Brazil: constraints on Brasiliano orogenic evolution of the Rio de La Plata cratonic margin. Journal of South American Earth Sciences, 21(3):204-227. https://doi. org/10.1016/j.jsames.2006.05.003

Saalmann K., Remus M.V.D., Hartmann L.A. 2007. Neoproterozoic magmatic arc assembly in the southern Brazilian Shield - constraints for a plate tectonic model for the Brasiliano orogeny. Geotectonic Research, 95(1):41-59. https://dx.doi.org/10.1127/1864-5658/07/0095-0041

Santos J.O.S., Chernicoff C.J., Zappettini E.O., McNaughton N.J., Hartmann L.A. 2019. Large geographic and temporal extensions of the Río de La Plata Craton, South America, and its metacratonic eastern margin. International Geology Review, 61(1):56-85. https://doi.org/10.1080/00206814.2017.1 405747

Santos T.J.S., Amaral W.D.S., Ancelmi M.F., Pitarello M.Z., Fuck R.A., Dantas E.L. 2015. U-Pb age of the coesite-bearing eclogite from NW Borborema Province, NE Brazil: Implications for western Gondwana assembly. Gondwana Research, 28(3):1183-1196. https://doi. org/10.1016/j.gr.2014.09.013

Serviço Geológico do Brasil (CPRM). 2010. Projeto Aerogeofísico Escudo do Rio Grande do Sul. Lasa Prospecções S.A., Technical report. CPRM, 260 p.

Slack J.F., Turner R.J.W., Ware P.L.G. 1998. Boron-rich mud volcanoes of the Black Sea region: Modern analogues to ancient sea-floor tourmalinites associated with Sullivan-type Pb-Zn deposits? Geology, 26(5):439-442. https://doi.org/10.1130/0091-7613(1998)026\%3C0439:BRMVOT\%3E 2.3.CO;2

Souza C.S.M., Hauser N., Dantas E.L., Reimold U., Schmitt R.T., Chaves J.G.S., Osorio L.F.B. 2019. Does the metavolcanic-sedimentary Rio do Coco Group, Araguaia Belt, Brazil, represent a continuity of the Quatipuru ophiolitic complex? - Constraints from $\mathrm{U}-\mathrm{Pb}$ and $\mathrm{Sm}-\mathrm{Nd}$ isotope data.
Journal of South American Earth, 94:102233. https://doi.org/10.1016/j. jsames.2019.102233

Stern R.J. 2018. Neoproterozoic formation and evolution of Eastern Desert continental crust - The importance of the infrastructure-superstructure transition. Journal of African Earth Sciences, 146:15-27. https://doi. org/10.1016/j.jafrearsci.2017.01.001

Strieder A.J., Nilson A.A. 1992. Estudo petrológico de alguns fragmentos tectônicos da mélange ofiolítica em Abadiânia (GO): 1 - O protólito dos corpos de serpentinito. Revista Brasileira de Geociências, 22(3):338-352.

Suita M.T.F., Pedrosa-Soares A.C., Leite C.A.S., Nilson A.A., Prichard H.M. 2004. Complexos ofiolíticos do Brasil e a metalogenia comparada das faixas Araçuaí e Brasília. In: Pereira E.S., Castroviejo R., Ortiz F. (Eds.), Complejos ofioliticos em Ibero América. Edita Proyecto XIII.1. Madrid: Government of Spain, p. 101-132.

Travassos R.P. 2014. Interpretação estrutural regional do Escudo Sul-RioGrandense - Rio Grande do Sul - Brasil, com base em aeromagnetometria. MS Dissertation, Universidade de Brasília, Brasília, 64 p.

van Hinsberg V.J., Henry D.J., Marschall H.R. 2011. Tourmaline: an idea indicator of its host environment. Canadian Mineralogist, 49(1):1-16. http://dx.doi.org/10.3749/canmin.49.1.1

Whitney D.L., Evans B.W. 2010. Abbreviations for names of rock-forming minerals. American Mineralogist, 95(1):185-187. https://doi.org/10.2138/ am.2010.3371

Xavier K.F., Oshiro Y., Pinto V.M., Hartmann L.A. 2018. Evolução do ofiolito Candiotinha, extremo sul do Escudo Brasileiro. In: Congresso Brasileiro de Geologia, Rio de Janeiro. Proceedings... SBG, 1 p.

Zenk M., Schulz B. 2004. Zoned Ca-amphiboles and related P-T evolution in metabasites from the classical Barrovian metamorphic zones in Scotland. Mineralogical Magazine, 68(5):769-786. https://doi. org $/ 10.1180 / 0026461046850218$

Zheng Z., Chen Y.-J., Deng X.-H., Yue S.-W., Chen H.-J., Wang Q.-F. 2019. Tourmaline geochemistry and boron isotopic variations as a guide to fluid evolution in the Qiman Tagh W-Sn belt, East Kunlun, China. Geoscience Frontiers, 10(2):569-580. https://doi.org/10.1016/j.gsf.2018.04.007 